\title{
Maize proteomic responses to separate or overlapping soil drought and two-spotted spider mite stresses
}

\author{
Anna Dworak ${ }^{1}$ Małgorzata Nykiel ${ }^{2}$ - Beata Walczak ${ }^{3}$ Anna Miazek ${ }^{2}$. \\ Dagmara Szworst-Lupina $^{2} \cdot$ Barbara Zagdańska $^{2} \cdot$ Małgorzata Kiełkiewicz $^{1}$
}

Received: 22 April 2016/ Accepted: 13 June 2016/Published online: 22 June 2016

(C) Springer-Verlag Berlin Heidelberg 2016

\begin{abstract}
Main conclusion In maize, leaf proteome responses evoked by soil drought applied separately differ from those evoked by mite feeding or both types of stresses occurring simultaneously.

This study focuses on the involvement of proteomic changes in defence responses of a conventional maize cultivar (Bosman) to the two-spotted spider mite infestation, soil drought and both stresses coexisting for 6 days. Under watering cessation or mite feeding applied separately, the protein carbonylation was not directly linked to the antioxidant enzymes' activities. Protein carbonylation increased at higher and lower SOD, APX, GR, POX, PPO activities following soil drought and mite feeding, respectively. Combination of these stresses resulted in protein carbonylation decrease despite the increased activity of all antioxidant enzymes (except the CAT). However, maize protein network modification remains unknown upon biotic/abiotic stresses overlapping. Here, using multivariate
\end{abstract}

Electronic supplementary material The online version of this article (doi:10.1007/s00425-016-2559-6) contains supplementary material, which is available to authorized users.

Małgorzata Kiełkiewicz

malgorzata_kielkiewicz@sggw.pl

1 Section of Applied Entomology, Faculty of Horticulture, Biotechnology and Landscape Architecture, Warsaw University of Life Sciences-SGGW, 159 Nowoursynowska, 02-776 Warsaw, Poland

2 Department of Biochemistry, Faculty of Agriculture and Biology, Warsaw University of Life Sciences - SGGW, 159 Nowoursynowska, 02-776 Warsaw, Poland

3 Institute of Chemistry, Silesian University, 9 Szkolna, 40-006 Katowice, Poland chemometric methods, 94 leaf protein spots (out of 358 considered; 2-DE) were identified (LC-MS/MS) as differentiating the studied treatments. Only 43 of them had individual discrimination power. The soil drought increased abundance of leaf proteins related mainly to photosynthesis, carbohydrate metabolism, defence (molecular chaperons) and protection. On the contrary, mite feeding decreased the abundance of photosynthesis related proteins and enhanced the abundance of proteins protecting the mite-infested leaf against photoinhibition. The drought and mites occurring simultaneously increased abundance of proteins that may improve the efficiency of carbon fixation, as well as carbohydrate and amino acid metabolism. Furthermore, increased abundance of the Rubisco large subunit-binding protein (subunit $\beta$ ), fructose-bisphosphate aldolase and mitochondrial precursor of Mn-SOD and decreased abundance of the glycolysis-related enzymes in the mite-free leaf (in the vicinity of miteinfested leaf) illustrate the involvement of these proteins in systemic maize response to mite feeding.

Keywords Antioxidants - Simultaneous stresses · Stress-related proteins - Tetranychus urticae .

Water deficiency $\cdot$ Zea
Abbreviations
APX Ascorbate peroxidase
CAT Catalase
GR Glutathione reductase
PEPC Phosphoenolpyruvate carboxylase
POX Guaiacol peroxidase
PPDK Pyruvate orthophosphate (Pi) dikinase
PPO Polyphenol oxidase
ROS Reactive oxygen species
SOD Superoxide dismutase 


\section{Introduction}

Under field conditions, crop plants are exposed to many unavoidable environmental fluctuations (e.g., soil water shortage, flooding, extreme temperatures, salinity, pathogen infection, arthropod herbivore attack). Most of the stress factors increase formation/accumulation of reactive oxygen species (ROS) that change cellular redox metabolism (Baxter et al. 2014). Major producers of ROS are electron transport chains in the chloroplast and mitochondria as well as apoplastic peroxidases and membrane bound NADPH-oxidases. To control ROS generation, plants engage an antioxidant defence system consisting of nonenzymatic antioxidants and ROS scavenging enzymes. The capabilities of ROS-scavengers are essential for the effectiveness of mechanisms protecting plants against ROS overabundance due to biotic/abiotic environmental factors (Foyer and Noctor 2011). At a low dosage, ROS act as second messengers in hormone signalling, coordinately regulating plant stress tolerance, while they cause oxidative damage when the level of ROS is overabundant (Foyer and Noctor 2011; Xia et al. 2015).

Although ROS involvement in plant stress tolerance differs from one stress to another, there is no doubt that ROS formation is required for both local and systemic signalling (Baxter et al. 2014; Xia et al. 2015 and rfs therein) and for activating stress response proteins, such as protein kinases, transcription factors, antioxidant enzymes and/or pathogenesis-related proteins (Atkinson and Urwin 2012). Thus, upon stress-related conditions, proteins appear to be the most frequently targeted by oxidative species. The most prevalent way of oxidatively modified protein formation is either oxidation of sulphur-containing residues of amino acids or oxidation of amino acid side chains to carbonyl derivatives (Levine 2002). On the other hand, redox regulation of proteins is required for activating efficient responses diminishing the negative effects on plant growth, development and productivity (Suzuki et al. 2014; Xia et al. 2015).

Much less is known about the metabolic background of plant responses to coexisting abiotic and biotic stresses, and the issue has not been fully examined yet (Prasch and Sonnewald 2015). However, recent evidence reveals that the effects of a joint action of two or more stresses differ from the effects of those occurring independently (Atkinson et al. 2013; Suzuki et al. 2014; Prasch and Sonnewald 2015). Furthermore, plants exposed to one type of stress develop resistance to other concurrently occurring stresses, and therefore, cross-tolerance to drought, cold, salinity and/ or heat is a common phenomenon (Atkinson and Urwin 2012; Suzuki et al. 2014; Prasch and Sonnewald 2015). For example, gene expression induced by low temperature is interrelated with the level of tissue dehydration tolerance, and thus, plant acclimation to cold or frost promotes the development of tolerance to a number of diverse environmental stresses (Grudkowska and Zagdańska 2010). In contrast, the combined drought and heat stresses had detrimental effect on the growth and productivity of barley and sorghum and it was much more pronounced than the one of the same stresses applied separately (Atkinson and Urwin 2012 and rfs therein; Rollins et al. 2013; Suzuki et al. 2014). Drought have been found to increase or decrease plant defence responses to insect herbivores due to hormonal signalling cross talk (Nguyen et al. 2016 and rfs therein).

Maize (Zea mays L.), the third agricultural crop worldwide and one of the most commonly cultivated cereals in Europe, is frequently exposed to soil water deficiency (Benešová et al. 2012) accompanied by the occurrence of a broad spectrum of arthropod herbivores (Meissle et al. 2013). In maize field crops, the European corn borer (ECB, Ostrinia nubilalis; Lepidoptera), aphid species (Rapalosiphum padi, Sitobion avenae, Metopolophium dirhodum; Hemiptera) and the Western corn rootworm (Diabrotica virgifera virgifera; Coleoptera) are the dominating insect herbivores, albeit many other herbivorous arthropods including the two-spotted spider mite, (Tetranychus urticae Koch, 1836; Acari, Prostigmata, Tetranychidae) frequently inhabit the crop (Cullen and Schramm 2009). The twospotted spider mite is a generalist with a piercing-sucking mode of feeding. At the site of mite feeding, saliva injection and chelicera mechanical damage trigger cytological/ metabolic changes (local responses) that may systemically impact both leaf tissues in the vicinity of mite-infested sites and other leaves within the mite-infested plant (Gawrońska and Kiełkiewicz 1999; Kielkiewicz 1999; Świątek et al. 2014). It may be controlled through JA-signalling (Zhurov et al. 2014) and/or by abscisic acid (ABA) or ethylene involvement (Gawrońska and Kiełkiewicz 1999; Kielkiewicz 2002). The mite-pest's outbreaks in the field are linked to prolonged hot weather and soil drought conditions (Cullen and Schramm 2009). However, the combined effect of soil drought and mites on plant fitness and tolerance has not yet been fully explained.

Recent studies have revealed that the type of stress such as soil drought or two-spotted spider mite infestation applied separately determined the response of key antioxidant maize enzymes (Świątek et al. 2014). Therefore, the question arises whether the combination of soil drought and mite stresses intensifies oxidative processes or induces distinct responses. To gain more insight into maize responses to co-occurring or separate stresses (drought and mite), the activity of ROS scavenging enzymes and their impact on the level of oxidized proteins as well as the leaf proteome profile were analysed and compared. We used 
two-dimensional polyacrylamide gel electrophoresis (2DE) and liquid chromatography-tandem mass spectrometry (LC-MS/MS) as tools for searching stress-related proteins that may contribute to maize tolerance. The conventional maize cultivar (Bosman), before reproductive growth stage $\left(\mathrm{V}_{11}\right)$, was chosen as plant material. Our results provide new evidence that jointly applied soil drought and mite-pest infestation lead to unique changes in the mature maize leaf proteome, differing from those caused by individual stress action, thus contributing to the knowledge on the $\mathrm{C} 4$ monocot responses to overlapping environmental stresses.

\section{Materials and methods}

\section{Plant material and experimental setup}

Plants of maize (Zea mays L. cv. Bosman, Hodowla Roślin Smolice Sp. z o.o. Grupa IHAR, Poland) were grown in individual pots filled with peat substrate under greenhouse conditions. Six-week-old plants at the eleven-leaf-stage $\left(\mathrm{V}_{11}\right)$ were either subjected to a two-spotted spider mite feeding, soil drought evoked by cessation of watering, or a combination of mite infestation and soil drought stresses for 6 days. The control plants, watered twice a day, were free of mites. The middle part of the maize leaf 8 (fully expanded) of the plants that were subjected to mite infestation was artificially colonised by fifty females (for details see Świątek et al. 2014). The mites were collected from a synchronized lab population continuously reared on bean plants at day/ night temperature of $24 / 18{ }^{\circ} \mathrm{C}$, at $16 / 8 \mathrm{~h}$ photoperiod. Miteinfested leaves were not overcrowded, and the source of food was sufficient to keep the mite females settled in place. After 6 days, leaves from the control and stress-treated plants were excised for further analyses. Additionally, the leaf 9, free of mites ('noninfested' from mite-infested plant) might receive a signal from 'mite-infested leaf 8 and the respective control leaf were collected. The relative water content (RWC) in each leaf was expressed as: RWC $(\%)=(\mathrm{FW}-\mathrm{DW}) /(\mathrm{SW}-\mathrm{DW})$, where $\mathrm{FW}$ means the leaf fresh weight, DW-the leaf dry weight, $105{ }^{\circ} \mathrm{C}$; SWthe leaf saturated weight (Barrs 1968).

Two series of independent experiments were carried out and six leaf samples collected from six plants were divided into six biological replicates and used for measuring enzyme activity, protein oxidation and protein profiles.

\section{Antioxidant enzyme activity measurements}

The activity of superoxide dismutase (SOD, EC 1.15.1.1) was measured on the basis of reduction of nitroblue tetrazolium (NBT) at $560 \mathrm{~nm}$ (Fridovich 1986). The enzyme extract was prepared from leaf tissue $(1 \mathrm{~g} \mathrm{FW})$ grounded in liquid nitrogen and extracted in a $5 \mathrm{ml}$ precooled extraction buffer $(50 \mathrm{mM}$ Tris- $\mathrm{HCl}$ pH 7.5) containing $1 \% \quad(\mathrm{w} / \mathrm{v})$ insoluble polyvinylpyrrolidone (PVP). The homogenate was centrifuged at $20,000 \mathrm{~g}\left(4{ }^{\circ} \mathrm{C} ; 20 \mathrm{~min}\right)$ and the supernatant was directly used for the enzyme assays. The reaction mixture contained $12.48 \mu \mathrm{M}$ riboflavin, $13 \mathrm{mM}$ methionine, $75 \mu \mathrm{M}$ NBT in a $0.1 \mathrm{M}$ phosphate buffer $\mathrm{pH} 7.8$ and $50 \mu \mathrm{l}$ of crude enzyme extract in the total volume of $2.5 \mathrm{ml}$. One unit of SOD activity was expressed as enzyme activity inhibiting the photoreduction of NBT to blue formazan by $50 \%$.

The ascorbate peroxidase (APX, EC 1.11.1.11) was extracted and assayed as described by (Nakano and Asada 1981). The enzyme extract was prepared from leaf tissue $(1 \mathrm{~g} \mathrm{FW})$ grounded in liquid nitrogen. Then $5 \mathrm{ml} 50 \mathrm{mM}$ phosphate buffer $\mathrm{pH} 7.0$ containing $1 \%(\mathrm{w} / \mathrm{v})$ insoluble PVP, $0.1 \mathrm{mM}$ EDTA and $2 \mathrm{mM}$ ascorbate was added. The homogenate was centrifuged at $15,000 \mathrm{~g}\left(4^{\circ} \mathrm{C} ; 20 \mathrm{~min}\right)$. The reaction mixture containing $0.1 \mathrm{mM} \mathrm{H}_{2} \mathrm{O}_{2}$ was incubated together with the enzyme extract $(30 \mu \mathrm{l})$ in the total volume of $1 \mathrm{ml}$. The change in absorbance at $290 \mathrm{~nm}$ was recorded every $10 \mathrm{~s}$ for $3 \mathrm{~min}$. The APX activity was calculated using an extinction coefficient for ascorbate $\left(2.8 \mathrm{mM}^{-1} \mathrm{~cm}^{-1}\right)$ and expressed as units per $\mathrm{mg}$ of protein, where one unit of APX activity was expressed as ascorbate $\mu$ moles oxidized per minute.

The catalase (CAT, EC 1.11.1.6) activity was measured by determining the degree of $\mathrm{H}_{2} \mathrm{O}_{2}$ decomposition at $240 \mathrm{~nm}$ for $2 \mathrm{~min}$ (Beers and Sizer 1952). An enzyme extract was prepared from leaf tissue $(1 \mathrm{~g} \mathrm{FW})$ grounded in liquid nitrogen and extracted in a $5 \mathrm{ml}$ pre-cooled extraction buffer $(50 \mathrm{mM}$ Tris- $\mathrm{HCl} \mathrm{pH} 7.5)$ containing $1 \%(\mathrm{w} /$ v) insoluble PVP. The homogenate was centrifuged at $20,000 \mathrm{~g}\left(4^{\circ} \mathrm{C} ; 20 \mathrm{~min}\right)$ and supernatant was directly used for the enzyme assays. The reaction mixture contained $20.4 \mathrm{mM} \mathrm{H}_{2} \mathrm{O}_{2}$ in a $50 \mathrm{mM}$ potassium phosphate buffer $\mathrm{pH}$ $7.0(1 \mathrm{ml}), 100 \mu \mathrm{l}$ of crude enzyme extract $(100 \mu \mathrm{l})$ and deionized water $(1.9 \mathrm{ml})$. One unit of CAT activity was expressed as $\mathrm{H}_{2} \mathrm{O}_{2}$ umoles $\left(39.4 \mathrm{mM}^{-1} \mathrm{~cm}^{-1}\right)$ removed per minute.

The glutathione reductase (GR, EC 1.6.4.2) activity in crude extract was assayed by monitoring the levels of NADPH glutathione-dependent oxidation at $340 \mathrm{~nm}$ (Foyer and Halliwell 1976). Leaf FW (0.1 g) was pulverised in liquid nitrogen and extracted with $2 \mathrm{ml} 50 \mathrm{mM}$ phosphate buffer pH 7.5 containing $1 \mathrm{mM}$ EDTA, $10 \mathrm{mM}$ sodium ascorbate and $0.2 \mathrm{~g}$ insoluble PVP. The homogenate was centrifuged at $15,000 \mathrm{~g}\left(4{ }^{\circ} \mathrm{C} ; 10 \mathrm{~min}\right)$. The assay mixture contained $50 \mathrm{mM}$ phosphate buffer $\mathrm{pH} 7.5$, $0.15 \mathrm{mM}$ NADPH, $10 \mathrm{mM}$ glutathione disulphide (GSSG) and the crude enzyme extract $(0.1 \mathrm{ml})$ in the total reaction 
volume of $1 \mathrm{ml}$. GR activity was expressed as NADPH nmol per mg of protein.

Using guaiacol as a substrate, the guaiacol peroxidase (POX, EC 1.11.1.7) activity was assayed. The enzyme extract was prepared from leaf tissue $(1 \mathrm{~g} \mathrm{FW})$ grounded in liquid nitrogen and extracted in a $5 \mathrm{ml} 50 \mathrm{mM}$ Tris- $\mathrm{HCl}$ pH 7.5 containing $1 \%(\mathrm{w} / \mathrm{v})$ insoluble PVP. The homogenate was centrifuged at $20,000 \mathrm{~g}\left(4{ }^{\circ} \mathrm{C} ; 20 \mathrm{~min}\right)$ and supernatant was directly used for enzyme assays. The reaction medium consisted of $4.5 \mathrm{mM}$ guaiacol $(0.5 \mathrm{ml})$ and $4.9 \mathrm{mM} \mathrm{H}_{2} \mathrm{O}_{2}(0.5 \mathrm{ml})$ in a $50 \mathrm{mM}$ acetate buffer $\mathrm{pH}$ $5.6(0.99 \mathrm{ml})$. The reaction was initiated by adding $10 \mu \mathrm{l}$ of crude enzyme extract (Patykowski et al. 2007) and an increase in absorbance at $470 \mathrm{~nm}$ was monitored for $4 \mathrm{~min}$. The POX activity was expressed as units per $\mathrm{mg}$ of protein where one unit of POX activity was expressed as guaiacol $\mu$ moles $\left(26.6 \mathrm{mM}^{-1} \mathrm{~cm}^{-1}\right)$ oxidized per minute.

The polyphenol oxidase (PPO, EC 1.14.18.1) was extracted and assayed as described by Zauberman et al. (1991) with some modifications. Leaf tissue ( $0.1 \mathrm{~g} \mathrm{FW})$ was pulverised in liquid nitrogen and extracted in a $2 \mathrm{ml}$ $50 \mathrm{mM}$ phosphate buffer $\mathrm{pH} 6.2$ containing $50 \mathrm{mM}$ EDTA. The homogenate was centrifuged at $15,000 \mathrm{~g}\left(4{ }^{\circ} \mathrm{C}\right.$; $10 \mathrm{~min})$. The reaction mixture consisted of a $50 \mathrm{mM}$ phosphate buffer $\mathrm{pH} 6.2,50 \mathrm{mM}$ pyrogallol and the enzyme extract $(0.1 \mathrm{ml})$ in the total volume of $1 \mathrm{ml}$. The conversion of pyrogallol to purpurogallin was measured at $420 \mathrm{~nm}$. The PPO activity was expressed as units per mg of protein where one unit of the enzyme activity was expressed as purpurogallin $\mu$ moles produced per minute.

The soluble protein content in leaf extracts was quantified using the Bradford (1976) method with bovine serum albumin (BSA) as a standard.

\section{Protein oxidation measurement}

The concentration of the derivatized carbonyl group of oxidized proteins in the presence of 2,4-dinitrophenylhydrazine (DNPH) was determined using the method of Levine et al. (1994). Briefly, maize leaf sample proteins were extracted in a $100 \mathrm{mM}$ phosphate buffer $\mathrm{pH} 7.8$ containing $1 \mathrm{mM}$ EDTA, $2 \mathrm{mM}$ PMSF and $1 \mu \mathrm{M}$ pepstatin. Aliquot extracts $(0.1 \mathrm{ml})$ were incubated with $10 \mathrm{mM}$ DNPH or $2.5 \mathrm{M} \mathrm{HCl}$ in darkness for $1 \mathrm{~h}$ (control). The proteins were precipitated with $20 \%$ trichloroacteic acid (TCA) and after $10 \mathrm{~min}$ centrifuged at $12,000 \mathrm{~g}$ for $10 \mathrm{~min}$. The protein pellet was washed with ethanol and ethyl acetate $(1: 1 ; \mathrm{v} / \mathrm{v})$ three times and dissolved in $6 \mathrm{M}$ guanidine hydrochloride in a $50 \mathrm{mM}$ potassium phosphate buffer $\mathrm{pH}$ 2.36. The absorbance was measured at $370 \mathrm{~nm}$. The carbonyl content was assessed using an extinction coefficient of hydrazone $\left(22,000 \mathrm{M}^{-1} \mathrm{~cm}^{-1}\right)$ and expressed as $\mathrm{C}=\mathrm{O}$ nmol per $\mathrm{mg}$ of protein.

\section{Statistical analysis}

The variance analysis (one-way ANOVA) at the $95 \%$ confidence level was used to assess differences in the activity of the leaf antioxidant enzymes as well as in the content of oxidized and total proteins. The Tukey's honestly significant difference (HSD) test and the nonparametric Kruskal-Wallis test were performed to separate means and medians, respectively. The significance level was set to 0.05 . The data are presented as the mean \pm SD. All statistical analyses were performed using Statistica 10.0 software.

\section{Leaf sample proteomic analysis setup}

To extract leaf proteins, the leaf samples $(0.3 \mathrm{~g})$ grounded in liquid nitrogen were resuspended in $2.0 \mathrm{ml} 10 \%$ TCA, dissolved in cold acetone, vortexed for $30 \mathrm{~s}$ and centrifuged at $10,000 \mathrm{~g}\left(4{ }^{\circ} \mathrm{C} ; 15 \mathrm{~min}\right)$. The fine powder was rinsed with cold $10 \%$ TCA in acetone until the supernatant was colourless. The pellet was washed with $0.1 \mathrm{M}$ ammonium acetate dissolved in $80 \%$ methanol and with cold $80 \%$ acetone. The pellet was vortexed, centrifuged (as above), dried and resuspended in a $0.8 \mathrm{ml}$ phenol and $0.8 \mathrm{ml}$ dense SDS buffer (30 \% sucrose, $2 \%$ SDS, $0.1 \mathrm{M}$ Tris-HCl, pH 8.0, $5 \%$ 2-mercaptoethanol). The mixture was vortexed for $3 \mathrm{~min}$. and the phenol phase was separated by centrifugation at $10,000 \mathrm{~g}$ for $30 \mathrm{~min}$. The upper phenol phase $(0.4 \mathrm{ml})$ was mixed with at least five volumes of cold methanol and $0.1 \mathrm{M}$ ammonium acetate and the mixture was stored at $-20^{\circ} \mathrm{C}$ for $30 \mathrm{~min}$. The precipitated proteins were dried and dissolved at $25^{\circ} \mathrm{C}$ for $16 \mathrm{~h}$ in a 2-DE rehydration solution (7 M urea, $2 \mathrm{M}$ thiourea, $4 \%$ w/v CHAPS, $2 \%$ v/v IPG buffer and $20 \mathrm{mM}$ DTT).

\section{Two-dimensional IEF/SDS-PAGE and protein staining}

Equal amounts of the extracted proteins $(150 \mu \mathrm{g})$ were separated by two-dimensional polyacrylamide gel electrophoresis (2-DE) as described by the Bio-Rad protein assay (Bio-Rad Laboratories). In the first dimension, IPG strips (Bio-Rad), each 11-cm long, were used. The $\mathrm{pH}$ was between 4 and 7. The isoelectric focusing (IEF) was performed using PROTEAN IEF Cell (Bio-Rad). The electrophoresis was initiated at $250 \mathrm{~V}$ for $20 \mathrm{~min}$, followed by $8000 \mathrm{~V}$ for $2.5 \mathrm{~h}$, and it was continued until reaching 20,000 Vh. The strips were equilibrated for $15 \mathrm{~min}$ in slow agitation in a Tris- $\mathrm{HCl}$ solution $(75 \mathrm{mM}), \mathrm{pH} 8.8$, containing $2 \% \mathrm{w} / \mathrm{v}$ SDS, 29, $3 \% \mathrm{v} / \mathrm{v}$ glycerol, $6 \mathrm{M}$ urea and $100 \mathrm{mM}$ DTT, and subsequently in Tris- $\mathrm{HCl}(50 \mathrm{mM}) \mathrm{pH}$ 6.8 containing $2 \%$ w/v SDS, 29, $30 \%$ v/v glycerol, $6 \mathrm{M}$ urea and $135 \mathrm{mM}$ IAA. After IEF, the proteins were 
separated by SDS-PAGE in the second dimension using $11 \%$ polyacrylamide gels. The gels were stained by the colloidal Coomassie G-250 method and scanned with the ImageScanner III (GE Healthcare). Six gels in two technical replications were run for each treatment.

\section{Gel image pre-processing and proteome profile evaluation}

Individual gel images require intense pre-processing prior to further data evaluation. In this study, the images were background corrected using the rolling ball method and warped to the selected standard (gel 2 from control leaf 8) (using the Fuzzy Warping approach (Daszykowski et al. 2007) (Fig. S1a-b). Normalized individual images were used to generate the mean image to detect spots and to construct the binary mask (Fig. S2a-c). A comparison of proteomic fingerprints was performed between control class [leaf 8; $\mathrm{C}(8)]$ and the class representing stress effect such as mite infestation $[\mathrm{Tu}+(8)]$, soil drought [D + (8)], the combination of mite infestation and soil drought stresses $[\mathrm{Tu}+\mathrm{D}(8)]$, as well as between class $[\mathrm{C}(9)]$ (control leaf 9 above leaf 8 ) and the class representing the indirect mite feeding effect on leaf 9 [Tu - (9)].

After pre-processing the gel images, a variance analysis was performed to test, if the compared classes of samples differed significantly. The variance analysis was performed at both, spot and pixel levels. PERMANOVA was the method of choice for variance analysis (Zerzucha et al. 2012). The randomization test was repeated 10,000 times and the significance level was set to 0.05 (Table 1). The identification of significant features (spots or pixels) was made using the uninformative variable elimination - partial least squares (UVE-PLS) (Zerzucha et al. 2012). Features selection was cross model validated; and depending on how frequently individual features were selected, a final set

Table 1 Variance analysis (PERMANOVA) performed at spots and pixel levels

\begin{tabular}{llllll}
\hline Classes compared & \multicolumn{2}{l}{ Spots (358) } & & \multicolumn{2}{c}{ Pixels $(17,616)$} \\
\cline { 2 - 3 } \cline { 6 - 7 } & $F$ & $P$ & & $F$ & $P$ \\
\hline $\mathrm{C}(8)$ and $\mathrm{Tu}+(8)$ & 1.3650 & 0.36 & & 1.7077 & $0.03^{*}$ \\
$\mathrm{C}(8)$ and $\mathrm{D}+(8)$ & 4.7774 & $0.01^{*}$ & & 2.2643 & $0.00^{*}$ \\
$\mathrm{C}(8)$ and $\mathrm{Tu}+\mathrm{D}(8)$ & 5.2811 & $0.00^{*}$ & & 2.6821 & $0.00^{*}$ \\
$\mathrm{C}(8)$ and $\mathrm{C}(9)$ & 3.7609 & $0.05^{*}$ & & 2.3190 & $0.00^{*}$ \\
$\mathrm{C}(9)$ and $\mathrm{Tu}-(9)$ & 2.9037 & 0.06 & & 2.8127 & $0.00^{*}$ \\
$\mathrm{Tu}+(8)$ and $\mathrm{Tu}-(9)$ & 4.4968 & $0.00^{*}$ & & 1.7687 & $0.00^{*}$ \\
\hline
\end{tabular}

Randomization test was performed 10,000 times

* Statistically significant differences (at significance level 0.05)

$F$ denotes the value of the $F$ test, and $P$ refers to the calculated significance level of the significant ones was built. The final set of significant features contains the ones which were selected in most cases (more than $50 \%$ ) (Table 2). The exploratory analysis of studied data was performed by a principal component analysis (PCA) followed by a hierarchical cluster analysis (HC) with the Euclidean distance as a similarity measure and Ward's linkage method.

\section{Protein identification by LC-MS/MS}

Selected protein spots were identified by liquid chromatography-tandem mass spectrometry (LC-MS/MS; nanoAcquity UPLC and Orbitrap type mass spectrometer) at the Mass Spectrometry Lab of the Institute of Biochemistry and Biophysics of Polish Academy of Sciences (Warsaw, Poland). Prior to the analysis, the excised gel slices were subjected to the standard procedure of in-gel trypsin digestion, during which the proteins were reduced with $100 \mathrm{mM}$ DTT at $56^{\circ} \mathrm{C}$ for $30 \mathrm{~min}$, alkylated with iodoacetamide at darkroom temperature for $45 \mathrm{~min}$ and digested overnight with $10 \mathrm{ng}^{-1} \mathrm{l}^{-1}$ trypsin. The peptides were eluted from the gel with water solution of $0.1 \%$ trifluoroactetic acid (TFA) and $2 \%$ acetonitrile (ACN). The resulting peptide mixtures were applied to the RP-18 precolumn (Waters, Milford, MA, USA), using water containing $0.1 \%$ formic acid (FA) as a mobile phase, and then transferred to the nano-HPLC RP-18 column (internal diameter $75 \mu \mathrm{M}$, Waters) using the ACN gradient (0-30\% $\mathrm{ACN}$ in $40 \mathrm{~min}$ ) in the presence of $0.1 \% \mathrm{FA}$ at a flow rate

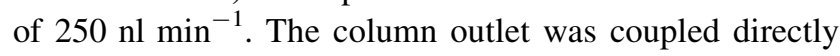
to the ion source of Orbitrap Velos mass spectrometer (Thermo) working in the regime of data-dependent MS to MS/MS switch. A blank run preceded each analysis to ensure that the previous samples had not been the cause of cross-contamination.

\section{Mass spectrometry data analysis}

After pre-processing the raw data with Mascot Distiller software (version 2.3, Matrix Science, London, UK), obtained peak lists were used to search the nonredundant protein database of the National Centre for Biotechnology Information (NCBI-NR) (23919380 sequences; 8216485116 residues) using the Mascot search engine (version 2.4, 8-processors onsite license) (Matrix Science) with the following search parameters: taxonomy restriction-Viridiplantae (Green Plants, 1249273 sequences), enzyme specificity - trypsin, permitted number of missed cleavages-1, fixed modification-carbamidomethylation (C), variable modifications - carboxymethyl (K), oxidation (M), protein mass - unrestricted, peptide mass tolerance$\pm 30 \mathrm{ppm}$, fragment mass tolerance- $\pm 0.6 \mathrm{Da}$. Only the peptides over the Mascot-defined expectation value of 0.05 
Table 2 The calculated significance values $(P)$ for protein spots differentially expressed when compared individually within the studied classes by the multivariate analysis (at $P<0.05$ )

\begin{tabular}{|c|c|c|c|c|c|}
\hline \multicolumn{6}{|c|}{ Protein spot number and $P$ value for classes compared } \\
\hline $\mathrm{C}(8)$ and $\mathrm{Tu}+(8)$ & $\mathrm{C}(8)$ and $\mathrm{D}+(8)$ & $\mathrm{C}(8)$ and $\mathrm{Tu}+\mathrm{D}(8)$ & $\mathrm{C}(8)$ and $\mathrm{C}(9)$ & $\mathrm{C}(9)$ and $\mathrm{Tu}-(9)$ & $\mathrm{Tu}+(8)$ and $\mathrm{Tu}-(9)$ \\
\hline $2 / 0.0396$ & $1 / 0.0013$ & $3 / 0.0036$ & $1 / 0.0069$ & $1 / 0.0069$ & $1 / 0.0142$ \\
\hline $10 / 0.0080$ & $3 / 0.0314$ & $4 / 0.0455$ & $2 / 0.0004$ & $2 / 0.0084$ & $3 / 0.0361$ \\
\hline $11 / 0.0289$ & 4/0.0001 & $5 / 0.0111$ & $5 / 0.0286$ & $5 / 0.0004$ & $5 / 0.0400$ \\
\hline \multirow[t]{10}{*}{$12 / 0.0357$} & $5 / 0.0015$ & $6 / 0.0114$ & $10 / 0.0041$ & $6 / 0.0286$ & $6 / 0.0202$ \\
\hline & $8 / 0.0077$ & $8 / 0.0058$ & & $13 / 0.0041$ & $8 / 0.0034$ \\
\hline & $11 / 0.0003$ & $13 / 0.0081$ & & & \\
\hline & $12 / 0.0440$ & $14 / 0.0122$ & & & \\
\hline & $13 / 0.0000$ & $15 / 0.0337$ & & & \\
\hline & $14 / 0.0001$ & $16 / 0.0125$ & & & \\
\hline & $17 / 0.0000$ & $23 / 0.0020$ & & & \\
\hline & $18 / 0.0000$ & $24 / 0.0143$ & & & \\
\hline & $20 / 0.0021$ & $26 / 0.0226$ & & & \\
\hline & 21/0.0199 & & & & \\
\hline $4^{+}$ & $13^{+}$ & $12^{+}$ & $4^{+}$ & $5^{+}$ & $5^{+}$ \\
\hline $12^{++}$ & $22^{++}$ & $26^{++}$ & $12^{++}$ & $14^{++}$ & $8^{++}$ \\
\hline
\end{tabular}

were considered positive identifications. Data concerning the results of LC-MS/MS are shown in Table 3. Detailed technical information is presented in Table S1 and https:// dl.dropboxusercontent.com/u/24272155/widma.zip.

\section{Results}

\section{Antioxidant enzyme response}

RWC in maize leaf 8 subjected to mite infestation for 6 days decreased by less than $5 \%$, while at the same time, the soil drought occurring alone and simultaneously with the mite infestation, caused a reduction of the leaf RWC by 46 and $48 \%$, respectively. Exposing the experimental maize plants to the soil drought and mite infestation overlapping stresses $(\mathrm{Tu}+\mathrm{D})$ increased the activity of all the antioxidant enzymes in leaf 8 , except for the CAT activity which markedly decreased (Fig. 1a-f). In contrast, the response of maize to mite infestation $(\mathrm{Tu}+)$ was not so uniform. In the mite-infested leaf 8 , the SOD and CAT activity (Fig. 1a-b) remained unchanged while the APX and PPO activity (Fig. 1c-f) declined and the GR and POX activity increased (Fig. 1d-e). On the other hand, the 6-day water deficit $(\mathrm{D}+)$ caused by soil water shortage significantly increased the activity of all the antioxidant enzymes, except for CAT (Fig. 1a-f). The GR and PPO activity was markedly elevated by about 400 and $500 \%$, respectively. It is worth mentioning that although no mites were presented on leaf 9 , the antioxidant enzymes became activated after leaf 8 had been mite-infested (Fig. 1a-f). However, the activity of antioxidant enzymes detected in mite-free leaf 9 changed in a different way, compared with the activity of antioxidant enzymes found in mite-infested leaf 8. For example, the APX activity increased by about $50 \%$ (Fig. 1c) while the SOD and GR activity decreased by more than 13 and $30 \%$ in mite-free leaf 9 (Fig. 1a,d). The CAT and POX activity did not change (Fig. 1b, e) while the PPO activity changed almost in the same way as in the case of mite-infested leaf 8 (Fig. 1f).

\section{Oxidative protein damage}

Grown under optimal (well-watered) conditions, the mature maize leaves 8 and 9 were not differentiated by the soluble protein level (Fig. 2a). After mite feeding $(\mathrm{Tu}+)$, deleterious effect on the leaf 8 protein content was noted, while the soluble protein content decreased by about $50 \%$ under the soil drought stress (D+) separately applied, and it remained at the same level under the combined drought and mite stresses $(\mathrm{Tu}+\mathrm{D})$.

To assess how much maize leaf proteins had been modified by various stresses, the protein carbonylation level was measured (Fig. 2b). The effect of soil drought and mite feeding applied together $(\mathrm{Tu}+\mathrm{D})$ differed from the one of a single stress. Both drought $(\mathrm{D}+)$ and mite feeding $(\mathrm{Tu}+)$ 


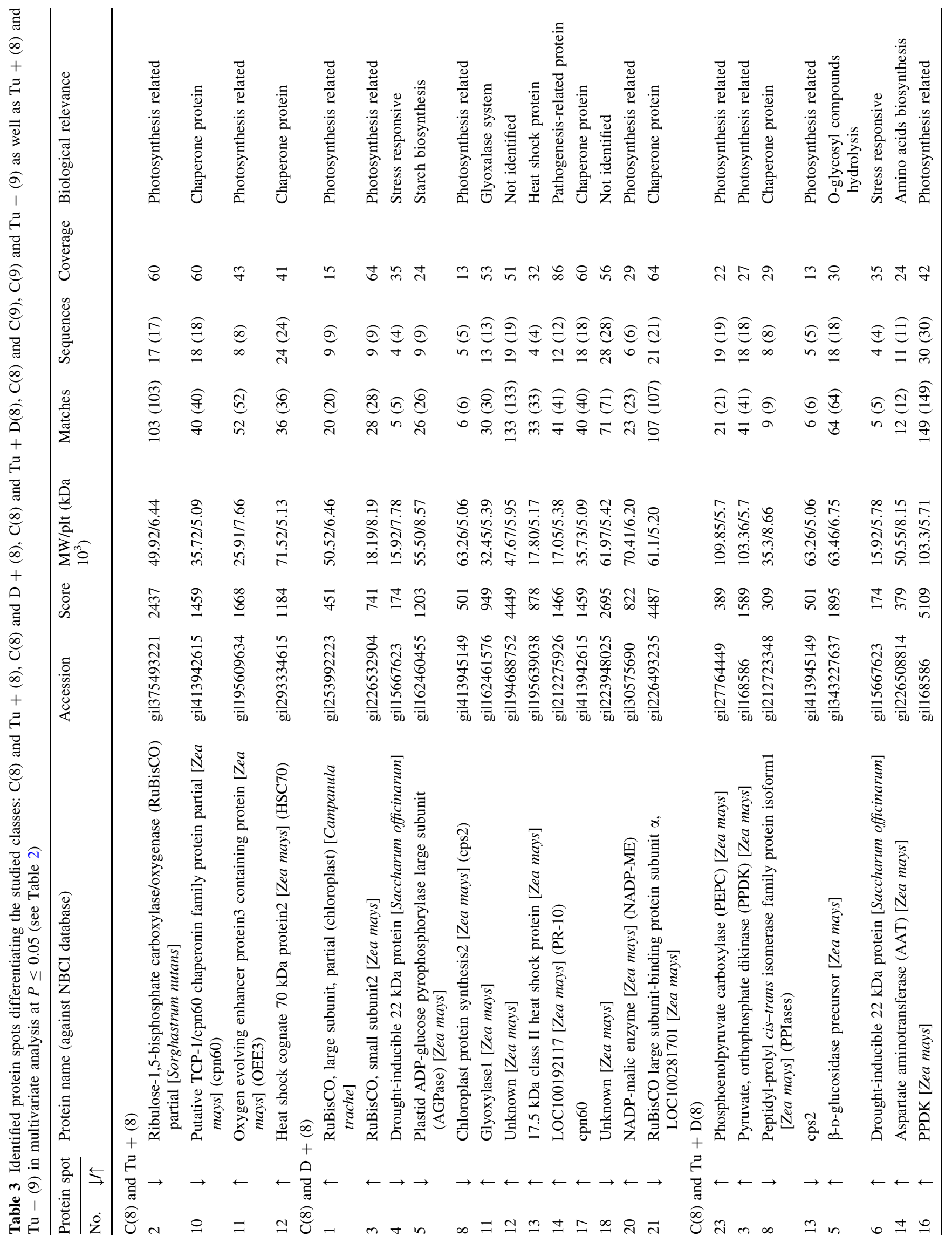




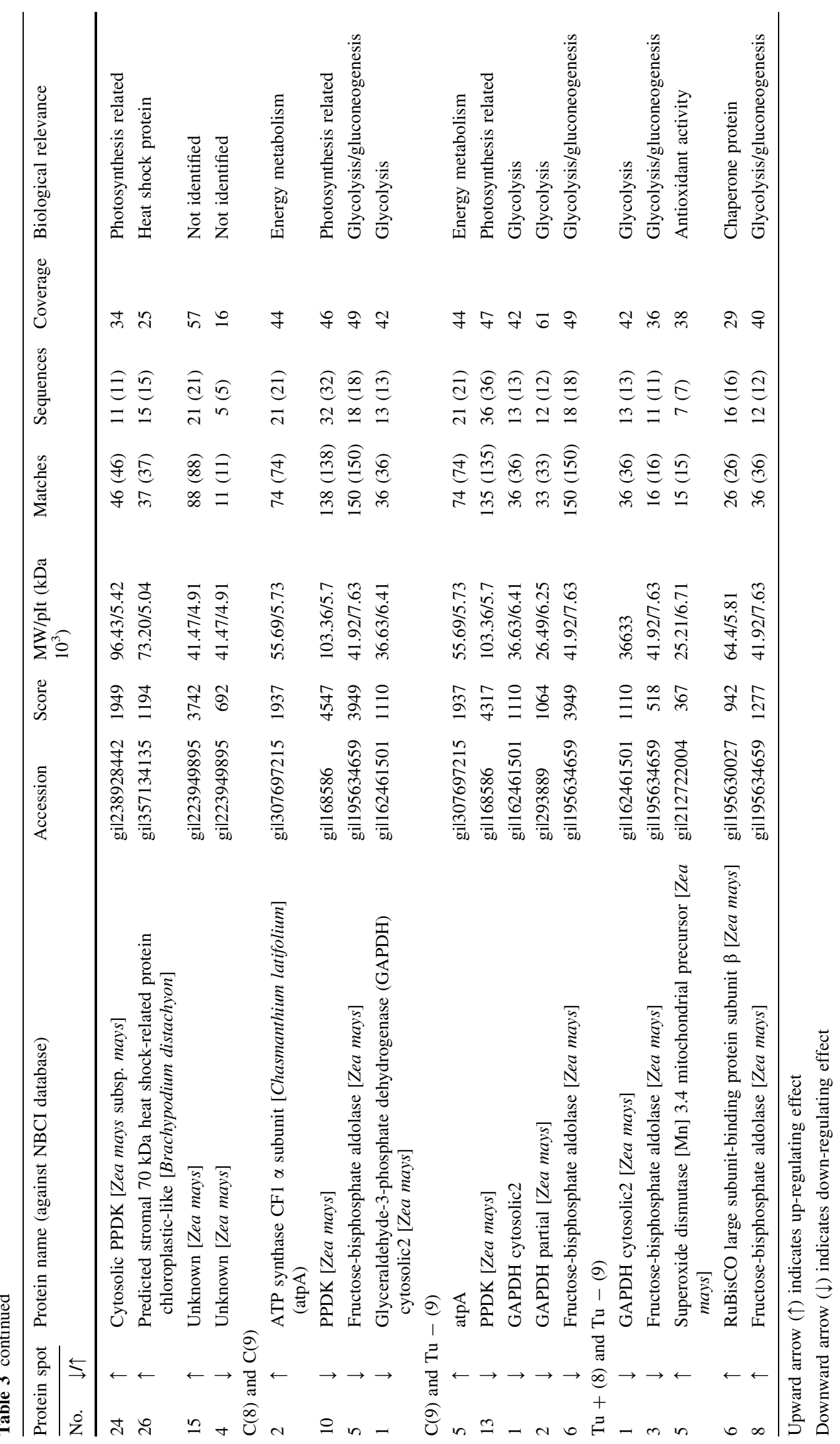


Fig. 1 a-f Superoxide dismutase (SOD, a), catalase (CAT, b), ascorbate peroxidase (APX, c), glutathione reductase (GR, d), guaiacol peroxidase (POX, e) and polyphenol oxidase (PPO, f) activity in maize leaf 8 grown under optimal control conditions (C), subjected to mite infestation $(\mathrm{Tu}+)$, soil drought $(\mathrm{D}+)$ and both stresses $(\mathrm{Tu}+\mathrm{D})$ simultaneously, and in noninfested leaf $9(\mathrm{Tu}-)$ in the immediate vicinity of miteinfested leaf 8 and respective control (C). Different letters above bars indicate statistically significant differences at the significance level 0.05 (a, b, c, f-HSD Tukey test; $\mathbf{d}, \mathbf{e}-$ Kruskal-Wallis test)
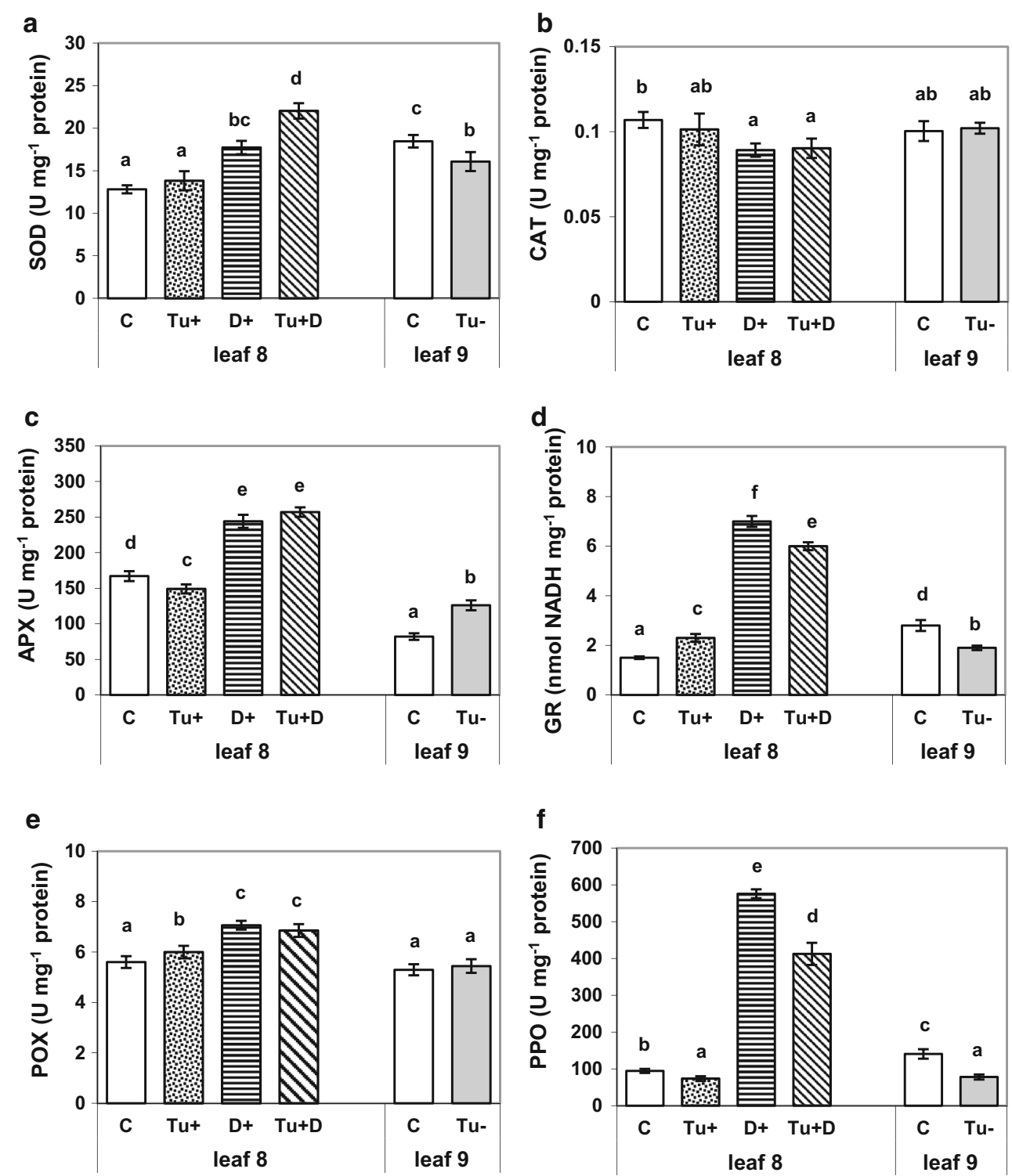

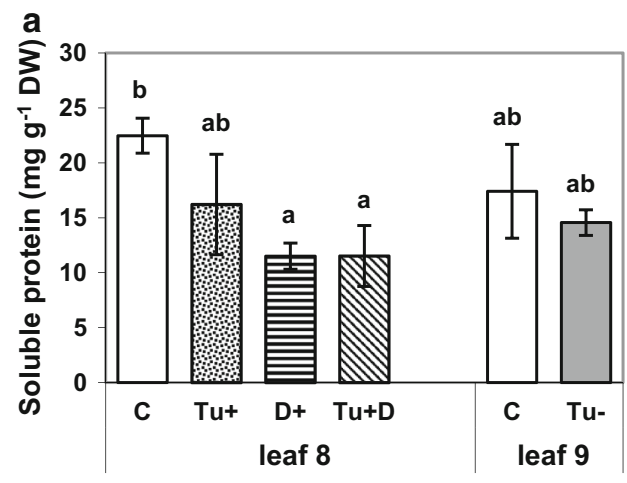

Fig. 2 a-b Total protein content (a) and the concentration of derivatized carbonyl groups of oxidized proteins $(\mathbf{b})$ in maize leaf 8 grown under optimal control conditions (C), subjected to mite infestation $(\mathrm{Tu}+)$, soil drought $(\mathrm{D}+)$ and both stresses $(\mathrm{Tu}+\mathrm{D})$

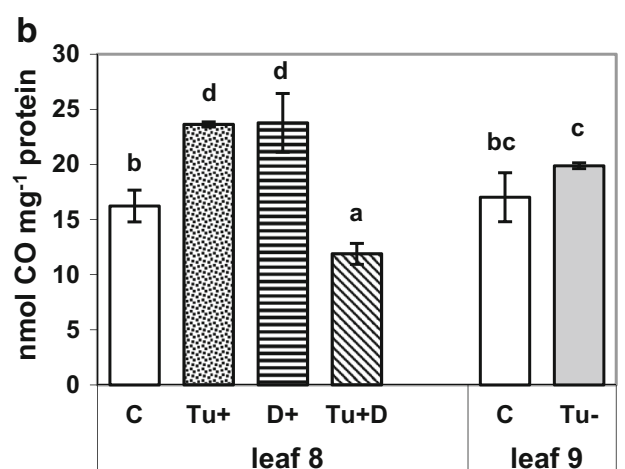

simultaneously, and in noninfested leaf $9(\mathrm{Tu}-)$ in the immediate vicinity of mite-infested leaf 8 and respective control (C). Different letters above bars indicate statistically significant differences at the significance level 0.05 (Kruskal-Wallis test) 
4
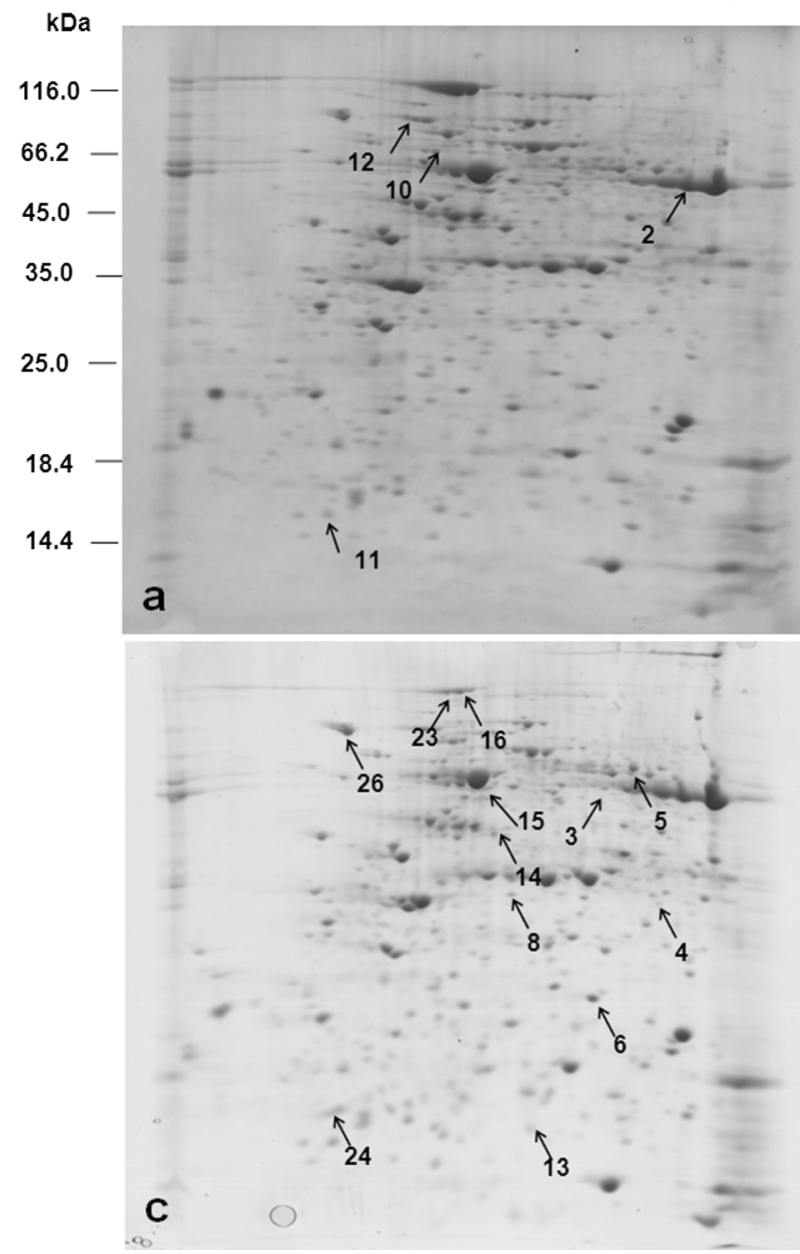
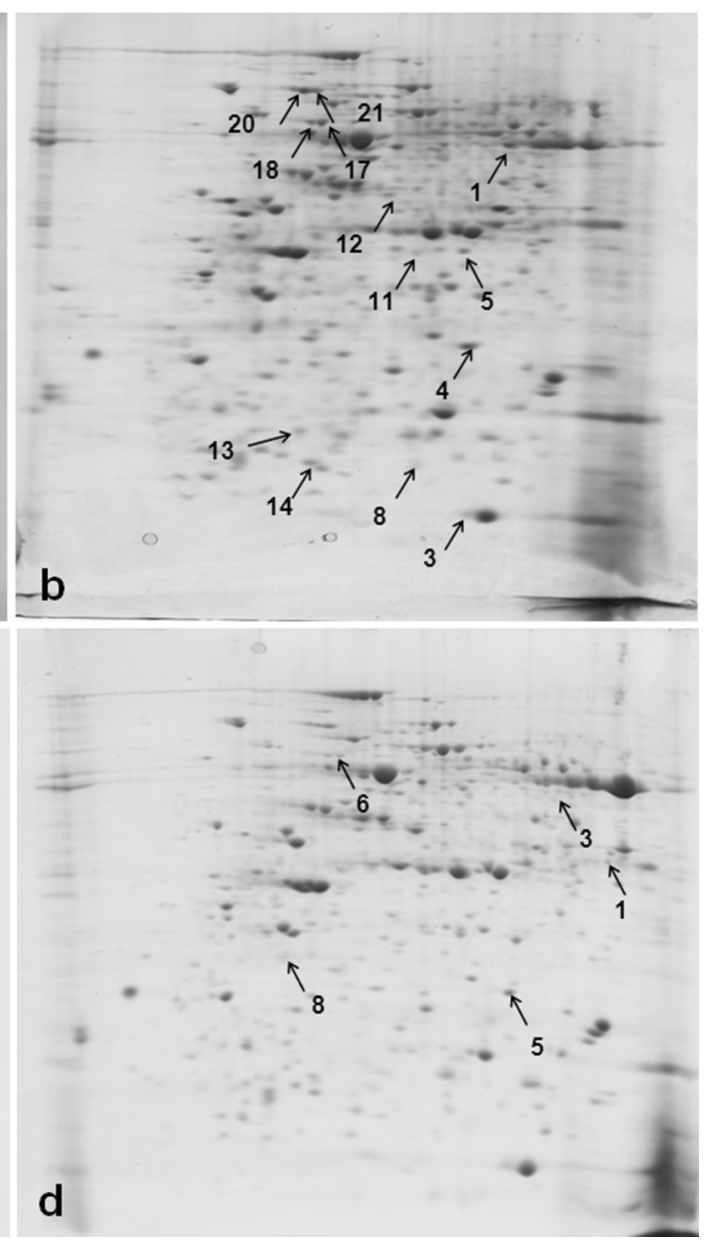

Fig. 3 a-d Representative 2-DE gels of CBB-stained proteins extracted from mite-infested leaf 8 (a), soil drought-treated (b), double-stressed (c), and from noninfested leaf 9 close to the miteinfested leaf 8 (d). Within each gel, numbers indicating protein spots differentiating treatment and unstressed control correspond to those in
Table 2 and 3. In the first dimension, IPG strips (Bio-Rad Laboratories, USA) of $\mathrm{pH} \mathrm{4-7} \mathrm{(indicating} \mathrm{p} I$ ) were used to separate proteins. In the second dimension, $11 \%$ polyacrylamide gel was used. Standard molecular masses $(\mathrm{kDa})$ are indicated

(at significance level 0.05). As each analysis performed on the spots has serious limitations (mainly due to the fact that the spots overlapped), the analysis was performed on a pixel level as well, and this time all the compared classes of samples were statistically different at the significance level of 0.05 (Table 1). Therefore, the further data analysis and feature selection were performed on the pixel level. Using the UVE-PLS method, a set of pixels significantly differentiating each pair of the compared classes was identified and assigned to the corresponding spots (from now on referred to as 'significant spots'). For leaf 8 samples, the significant spots differentiating the studied class pairs were marked on the mean image in Fig. $4 \mathrm{a}-\mathrm{c}$. There were 12 spots differentiating the control $[\mathrm{C}(8)]$ and the mite-infested leaf $8[\mathrm{Tu}+(8)]$ (Fig. 4 a), 22 spots differentiating the control $[\mathrm{C}(8)]$ and the drought-stressed leaf $8[\mathrm{D}+(8)]$ (Fig. 4 b) and 26 spots differentiating the control [C(8)] 

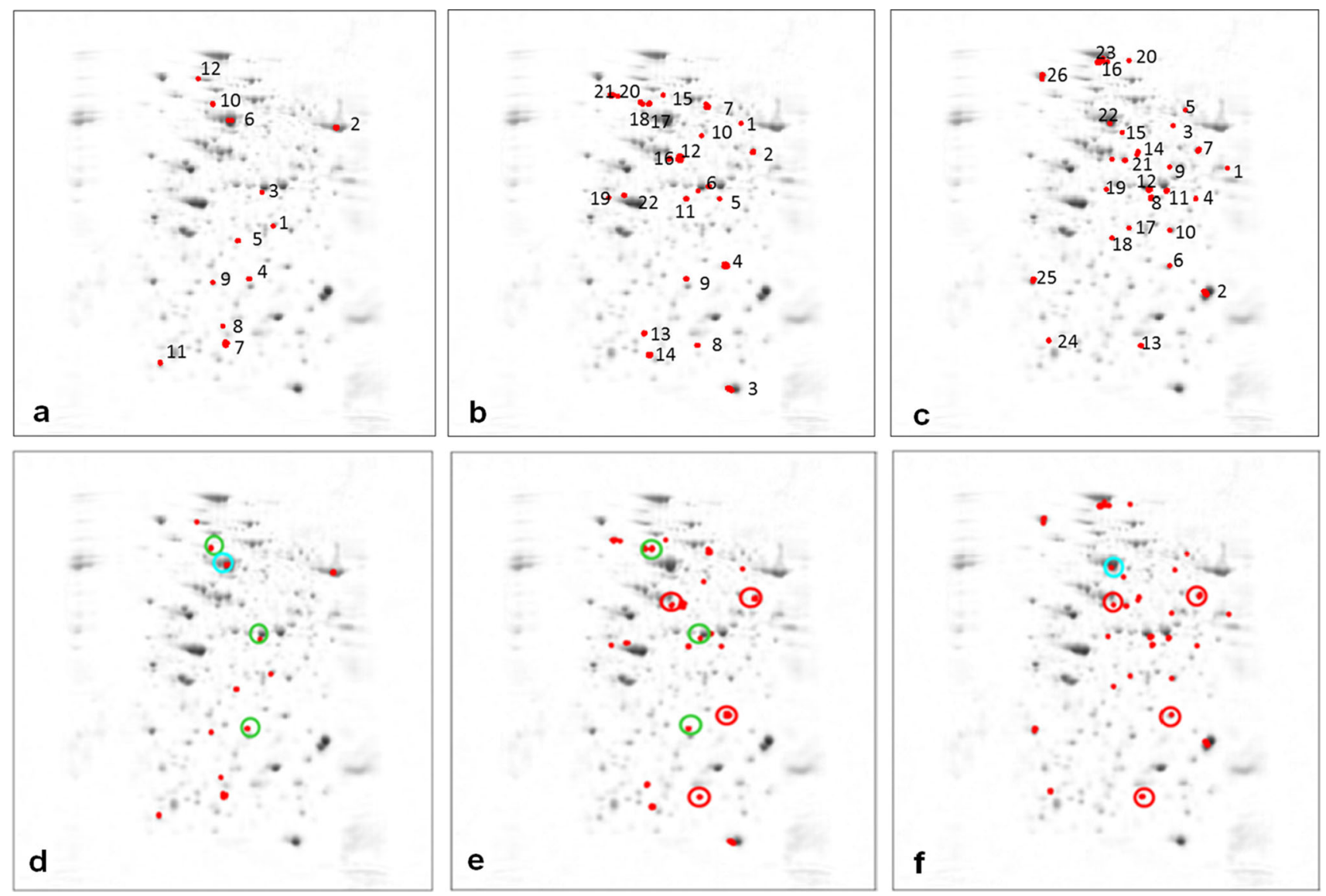

Fig. 4 a-f Representative mean images with marked significant spots differentiating the classes- $\mathrm{C}(8)$ and $[\mathrm{Tu}+(8)](\mathbf{a}), \mathrm{C}(8)$ and $[\mathrm{D}+(8)](\mathbf{b})$ and $\mathrm{C}(8)$ and $[\mathrm{Tu}+\mathrm{D}(8)](\mathbf{c})$. Below, mean images presenting the spots shared by mite $[\mathrm{Tu}+(8)]$ and drought $[\mathrm{D}+(8)]$

and the simultaneously stressed leaf $8[\mathrm{Tu}+\mathrm{D}(8)]$ (Fig. 4 c). Three significant spots (marked green) were shared by mite infestation and soil drought stresses (Figs. 4 d, e). Of all the significant spots representing the effect of soil drought stress, four spots (marked red, Fig. 4e) were also shared by both stresses (Figs. 4f) while one spot (marked blue) was shared by the single mite and both stresses (Fig. 4d, f).

When studying the proteomic profiles of leaf 9 , the following classes were compared: $[\mathrm{C}(8)]$ and $[\mathrm{C}(9)],[\mathrm{C}(9)]$ and $[\mathrm{Tu}-(9)]$ as well as $[\mathrm{Tu}+(8)]$ and $[\mathrm{Tu}-(9)]$. The identified significant spots $(12,14$ and 8$)$ marked on the mean image are presented in Fig. 5a-c, respectively.

While doing a multivariate discriminant analysis, it is possible to identify the features which are significant for classes discrimination but which do not individually differentiate the studied classes of samples (a univariate approach). As far as our study is concerned, of all the 12 spots differentiating the $\mathrm{C}(8)$ and $\mathrm{Tu}+(8)$ classes in the multivariate analysis, only four spots were significantly different when compared individually, while of all the 22 stresses (marked green; $\mathbf{d}$ and $\mathbf{e}$ ), by drought $[\mathrm{D}+(8)]$ and double stresses $[\mathrm{Tu}+\mathrm{D}(8)]$ (marked red; $\mathbf{e}$ and f) and by mite $[\mathrm{Tu}+(8)]$ and double stresses $[\mathrm{Tu}+\mathrm{D}(8)]$ (marked blue; $\mathbf{d}$ and $\mathbf{f}$ )

spots differentiating the $\mathrm{C}(8)$ and $\mathrm{D}+(8)$ classes only 13 were significantly different (Table 2 ). Similarly, of all the 26 spots differentiating the $\mathrm{C}(8)$ and $\mathrm{Tu}+\mathrm{D}(8)$ classes only 12 spots were significantly different. Additionally, there were 12,14 and 8 spots differentiating classes $\mathrm{C}(8)$ and $\mathrm{C}(9), \mathrm{C}(9)$ and $\mathrm{Tu}-(9)$ as well as $\mathrm{Tu}+(8)$ and $\mathrm{Tu}-(9)$, however, the number of spots significantly different (when compared individually) was much lower: 4, 5 and 5, respectively (Table 2). Therefore, only those individually different protein spots were further subjected to the LC-MS/MS and then they were compared with the nonredundant protein database of NCBI.

Using the results from the PCA, a certain insight into the biotic/abiotic stress impacts on the leaf proteome can be gained. To reveal the differences between leaf 8 samples, a PCA was performed on the (centred) data matrix containing all the features identified as significantly differentiating the classes of samples with the induced effect(s) (mite, soil drought, and the combination of soil drought and mite stresses) from the control one. The principal components (PCs) were constructed as linear combinations of the 

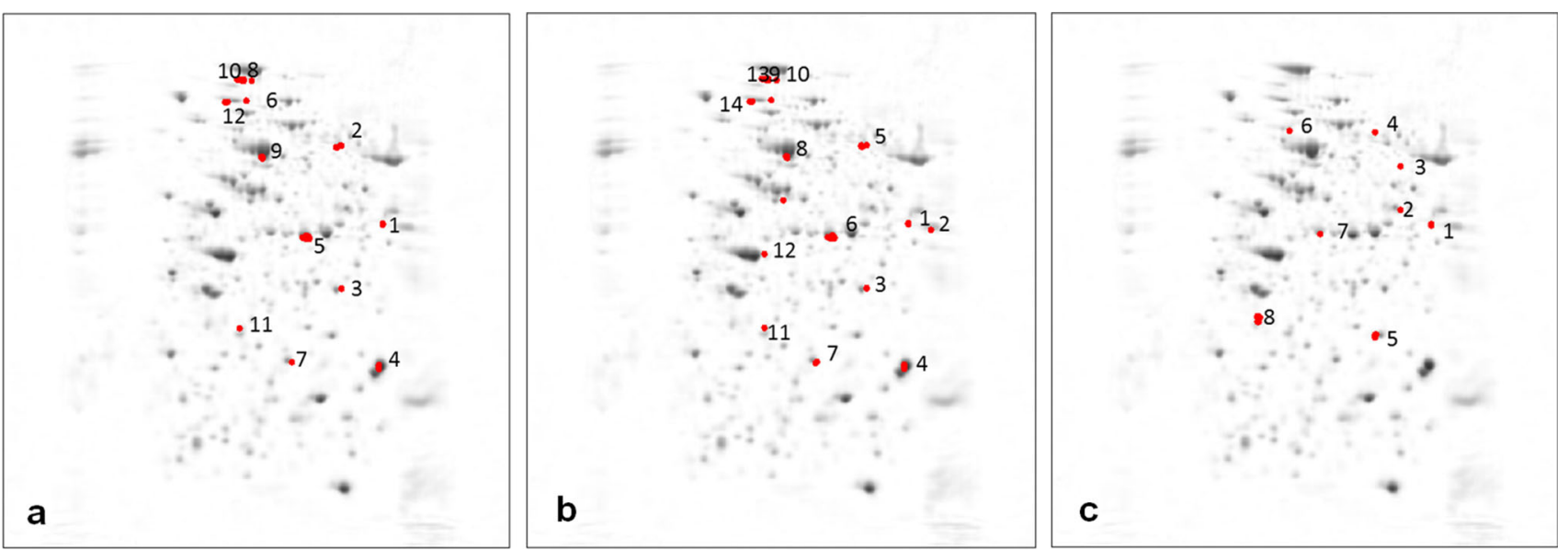

Fig. 5 a-c Representative mean images with marked significant spots differentiating classes $\mathrm{C}(8)$ and $\mathrm{C}(9)(\mathbf{a}), \mathrm{C}(9)$ and $\mathrm{Tu}-(9)(\mathbf{b}), \mathrm{Tu}+(8)$ and $\mathrm{Tu}-(9)(\mathbf{c})$

original features to maximize the description of data variance. The PCA made it possible to compress the obtained data into a few orthogonal hidden factors (PCs) and to visualise them in the low dimensionality space defined by PCs. The results from PCA are presented in the form of score and loading plots, representing projections of samples and features (pixels) onto the planes defined by the respective PCs. Score plots of 24 leaf 8 samples drawn on the planes and defined by PC1 and PC2, and PC1 and PC3, respectively, are presented in Fig. 6a-d. Looking at the previously discussed data set, the first three PCs describe 36, 20 and $10 \%$ data variance, respectively. Each sample is represented by a point. If the points are close to each other, they have similar proteomic profiles. If they are apart, their proteomic profiles differ to a high degree. These projections reveal that the biggest difference in proteomic profiles, observed along $\mathrm{PC} 1$, is between the control class $[C(8)]$ and the soil drought class [D + (8)] (Fig. 6a). Classes $\mathrm{Tu}+(8)$ and $\mathrm{Tu}+\mathrm{D}(8)$ have similar coordinates on PC1 (close to zero) (Fig. 6a). PC2 reveals the difference of class $\mathrm{Tu}+\mathrm{D}(8)$ from all the remaining classes (Fig. 6a), whereas the difference between class $\mathrm{Tu}+(8)$ and all the remaining classes is observed along PC3 (Fig. 6b). The PCA result proves that the soil drought stress influences protein profiles to the highest degree, whereas a combined effect of the soil drought and mite infestation has a relatively weaker effect on maize leaf 8 proteome. The corresponding loading plots presented in Figs. $6 \mathrm{c}-\mathrm{d}$, allow identifying the features (pixels) responsible for the observed sample patterns. The pixels within the green, blue and red cycles contribute to $\mathrm{PC} 1, \mathrm{PC} 2$ and $\mathrm{PC} 3$, respectively, to the highest degree.

The PCA score plots of all the six studied classes, i.e., of the 36 both leaf 8 and 9 samples, are presented in Fig. 7ad. As shown, PC1 has not differentiated between leaf 8 and
9 (Fig. 7a-b). The differences between leaf 8 and 9 are mainly revealed by PC2 (and PC3, but to certain degree though). PC2 describes the differences between the $\mathrm{C}(9)$ and $\mathrm{Tu}-(9)$ classes (Fig. 7a). PC3 reveals the specificity of class $\mathrm{Tu}+\mathrm{D}(8)$ (Fig. 7b). The $\mathrm{D}+(8)$ class samples display the greatest variance, whereas the remaining classes are more homogenous. The corresponding loading plots (Fig. 7c-d) revealed that the same pixels as in the case of the analysis of the 24 samples are responsible for designing the observed pattern of the 36 samples. It should be stressed that the patterns revealed in the PCA score plots represent the 66 and $72 \%$ data variance only for 24 and 36 samples, respectively. Taking into account the total data variance, $\mathrm{HC}$ analysis was applied. The results of $\mathrm{HC}$ analysis are presented in the form of dendrograms. The indices of the clustered objects (or variables) are displayed on axis $x$ of the dendrograms, whereas axis y represents the corresponding similarity measure between the two merging objects or clusters. Dendrograms obtained for the data sets containing 24 leaf 8 samples and 36 leaf 8 and 9 samples are presented in Figs. 8 and 9. They are augmented with heat maps (Smoliński et al. 2002) representing transposed data matrices. The rows of the matrices represent pixels and the columns represent samples. Matrix columns are sorted out in the dendrograms of the above samples, whereas rows are sorted out in the dendrogram of pixels. The way the samples are clustered is based on the Euclidean distance, whereas the way the pixels are clustered is based on their correlation.

In the dendrogram of leaf 8 samples (Fig. 8), there are four main subgroups corresponding to the studied sample classes. Sub-clusters $\mathrm{Tu}+(8)$ and $\mathrm{Tu}+\mathrm{D}(8)$ are more similar to each other than to the remaining sub-clusters. They are more similar to $\mathrm{C}(8)$ than to $\mathrm{D}+(8)$, i.e., the most dissimilar is class $\mathrm{D}+(8)$. The heat map indicates 

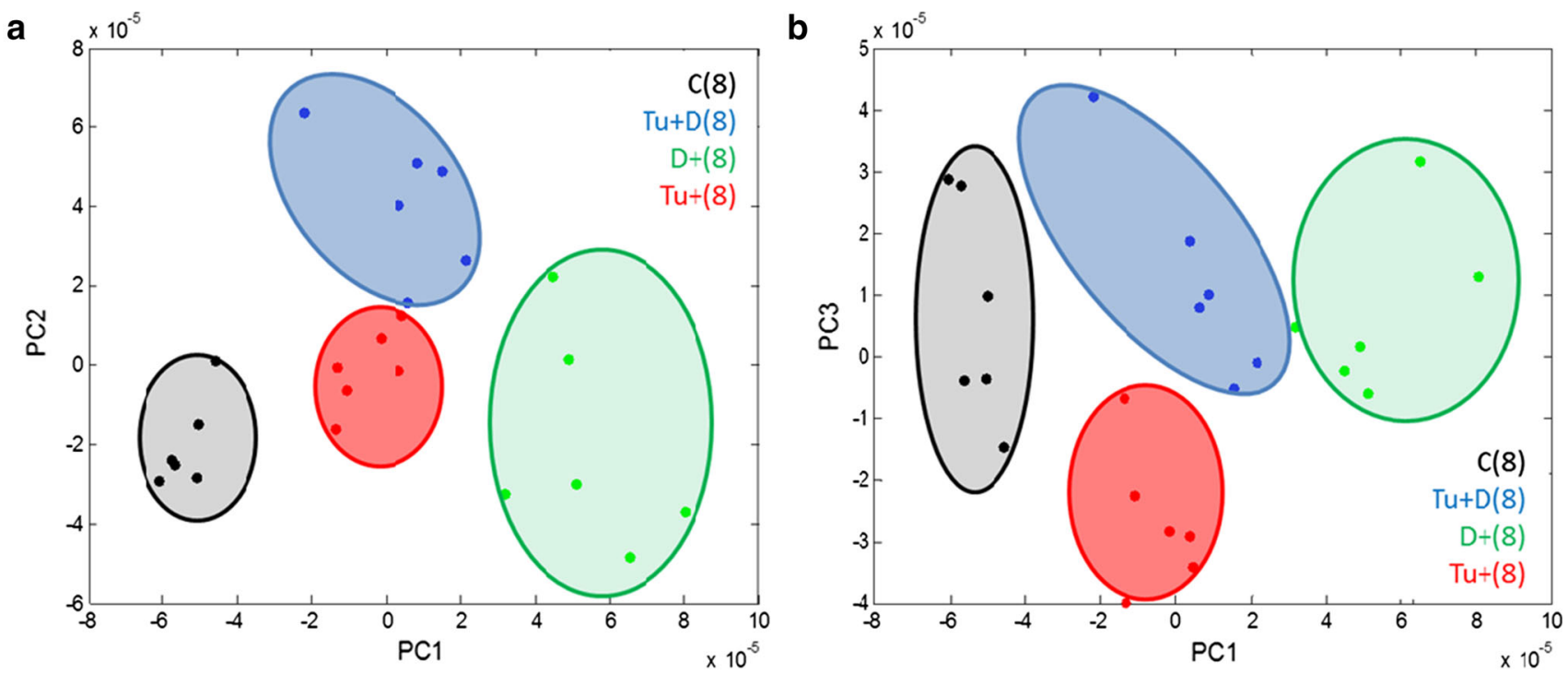

\section{Score plots}
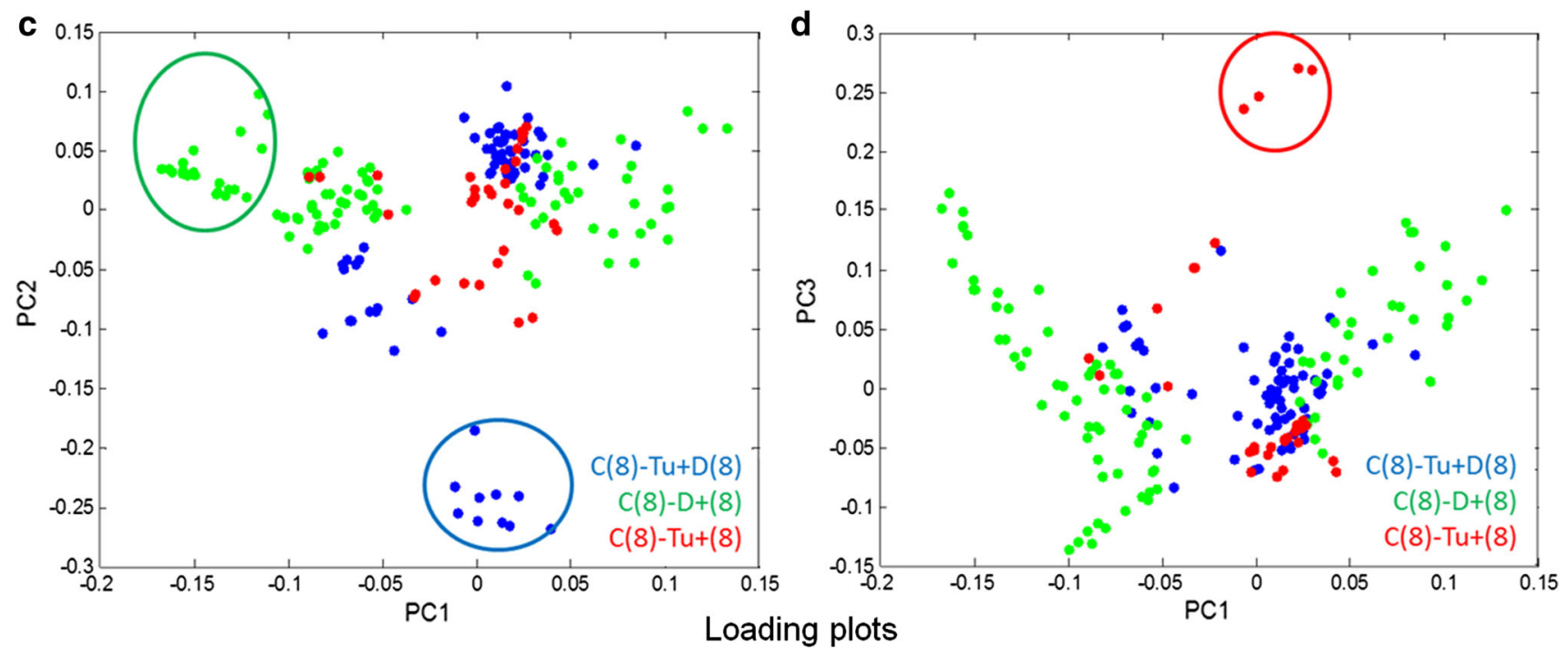

Fig. 6 a-d The results from PCA of 24 samples obtained from four classes $C(8), T u+(8), T u+D(8)$ and $D+(8)$ presented in the form of score $(\mathbf{a}, \mathbf{b})$ and loading plots $(\mathbf{c}, \mathbf{d})$ onto the planes defined by $\mathrm{PC} 1$ and $\mathrm{PC} 2$, and $\mathrm{PC} 1$ and $\mathrm{PC} 3$, respectively

which pixels are responsible for which (previously observed) clustering pattern. The results of the clustering 36 samples (Fig. 9) are quite consistent with the corresponding PCA results (Fig. 7a-d). The observed 6 subclusters of the studied samples correspond well with the 6 studied classes (the exception is one sample from class $\mathrm{C}(9)$, which appears in the cluster of the $\mathrm{Tu}+(8)$ samples. The structure of the dendrogram reveals similarities between $\mathrm{C}(8)$ and $\mathrm{C}(9)$ and between $\mathrm{Tu}+(8)$ and $\mathrm{Tu}-(9)$. Class $\mathrm{Tu}+\mathrm{D}(8)$ is more similar to the subcluster containing the samples from classes $\mathrm{Tu}+(8)$ and $\mathrm{Tu}-(9)$ than to the remaining classes. The most dissimilar is class $\mathrm{D}+(8)$. To sum up, short-term soil drought causes greater changes in the leaf proteome profile than mite infestation. When occurring simultaneously, joint stress leads to specific changes in the proteome profile.

\section{Proteins identified under single and combined stresses}

Table 3 presents detailed information (protein accession number, identification scores, molecular mass and isoelectric points, etc.) concerning 43 protein spots identified by LC-MS/MS. However, four proteins remain unknown due to the lack of their database matches while two have not been fully characterized. Additionally, all the other information concerning identified proteins (peptide sequences and modification sites located in the selected peptides, peptide scores, charge, theoretical and expected 

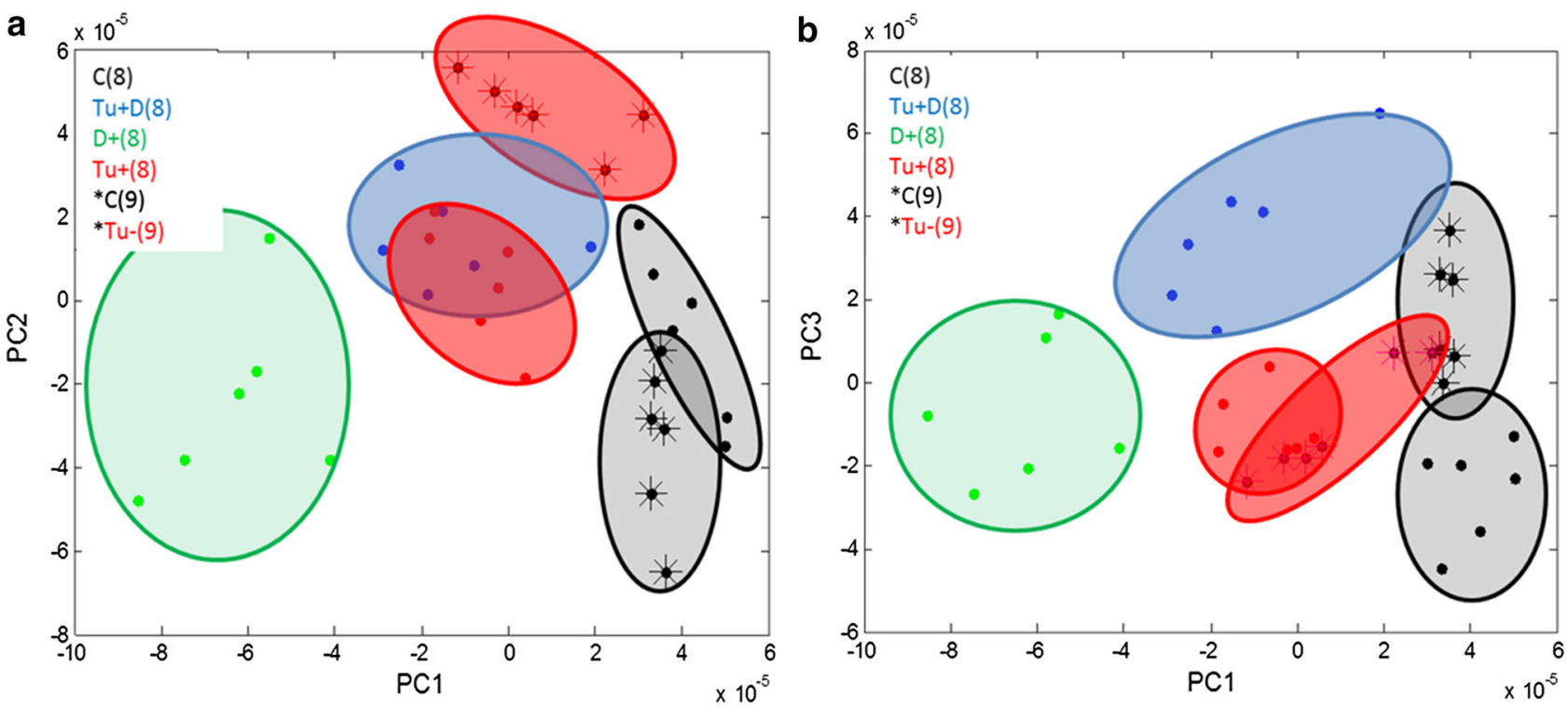

\section{Score plots}

C

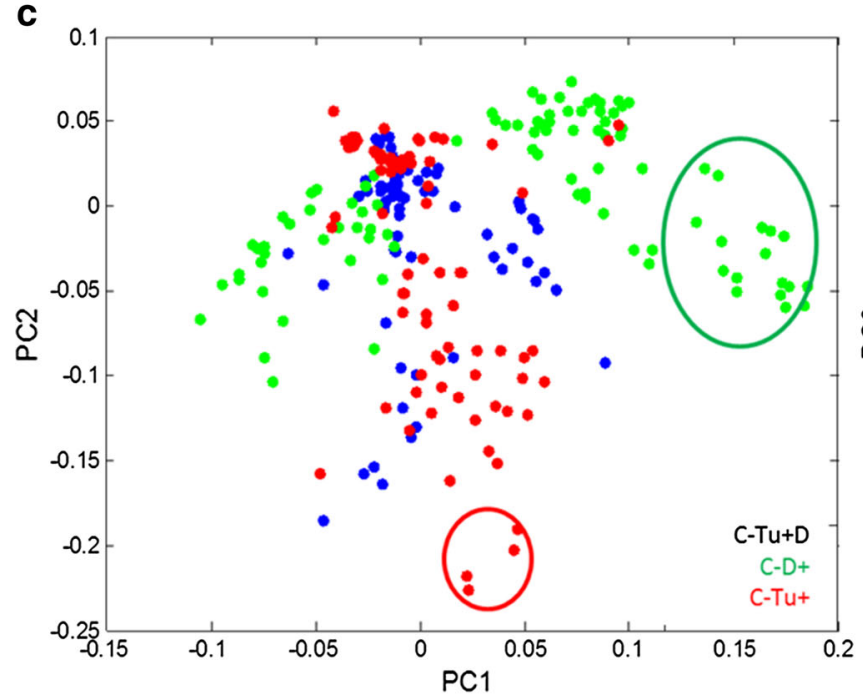

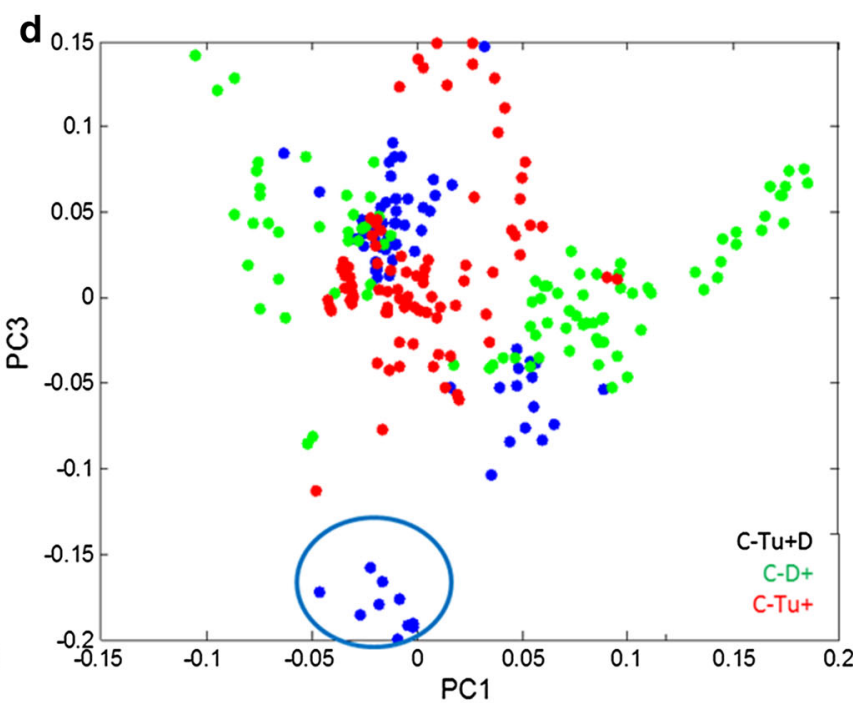

\section{Loading plots}

Fig. 7 a-d The results from PCA of 36 samples obtained from six classes $\mathrm{C}(8)$, $\mathrm{Tu}+(8), \mathrm{Tu}+\mathrm{D}(8), \mathrm{D}+(8), \mathrm{C}(9)$ and $\mathrm{Tu}-(9)$ presented in form of score $(\mathbf{a}, \mathbf{b})$ and loading plots $(\mathbf{c}, \mathbf{d})$ onto the planes defined by PC1 and PC2, and PC1 and PC 3 , respectively

molecular weights, retention time) is shown in Table S1 and https://dl.dropboxusercontent.com/u/24272155/widma. zip.

The proteomic analysis showed that in the mite-damaged leaf $8[\mathrm{Tu}+(8)]$, heat shock cognate $70 \mathrm{kDa}$ protein2 (HSC70), characteristic for stress response, and oxygen evolving enhancer protein3 containing protein (OEE3), involved in the functioning of the photosystem II (PSII) complex, were increased in abundance, whereas the abundance of ribulose-bisphosphate carboxylase/oxygenase (RuBisCO; EC 4.1.1.39), a crucial contributor to the Calvin-Benson cycle, and putative TCP-1/cpn60 chaperonin family protein (cpn60) were decreased (Table 3). In response to soil water deficit $[D+(8)]$ eight proteins in leaf 8 were increased in abundance (Table 3 ). Three of them, small and large RuBisCO subunits and NADP-malic enzyme (L-malate: NADP oxidoreductase, oxaloacetate decarboxylating, EC 1.1.1.40; NADP-ME) are related to photosynthesis; $17.5 \mathrm{kDa}$ class II heat shock protein, cpn60 and LOC 100192117 (pathogenesis-related PR-10 protein) are defence/stress responsive; glyoxylase1 (lactoylglutathione lyase; EC 4.4.1.5) is involved in recycling the reduced glutathione $(\mathrm{GSH})$ and maintaining glutathione homeostasis. Four of the identified proteins (i.e., droughtinducible $22 \mathrm{kDa}$ protein, plastid ADP-glucose pyrophosphorylase large subunit (ADP-GlcPPase; EC 2.7.7.27), 
Fig. 8 Dendrograms for 24 samples obtained from four classes $[\mathrm{C}(8), \mathrm{Tu}+(8)$, $\mathrm{Tu}+\mathrm{D}(8), \mathrm{D}+(8)]$ augmented with the heat map of centred data matrix (with columns and rows sorted out in the corresponding dendrograms). Gradations of colour from dark blue to red in the colour bar indicate the increase in value of data elements

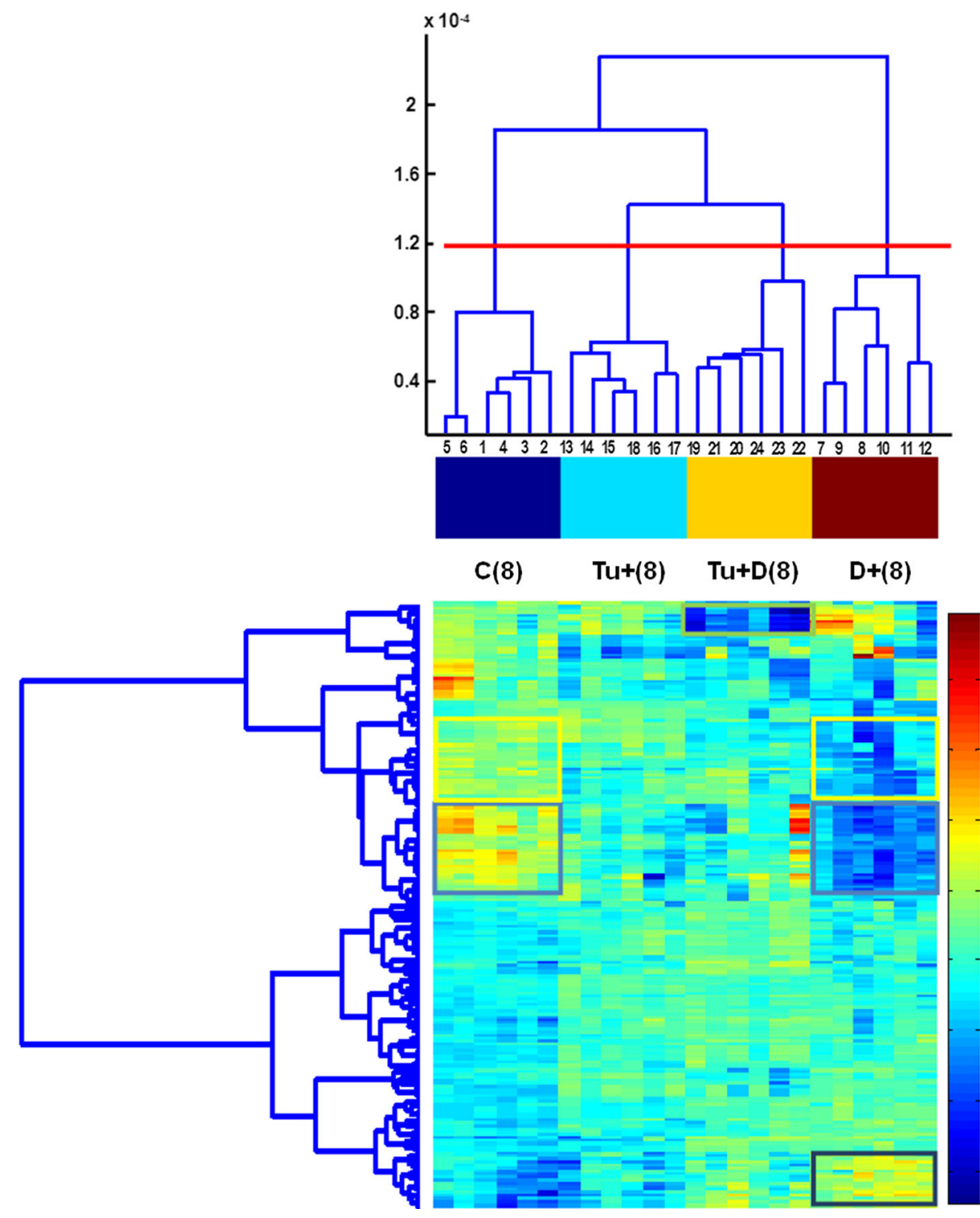

chloroplast protein synthesis2 (cps2), and LOC 100281701 (RuBisCO large subunit-binding protein subunit $\alpha$ ) were decreased in abundance.

In leaf 8 , in response to both mite feeding and soil drought stresses $[\mathrm{Tu}+\mathrm{D}(8)]$ phosphoenolpyruvate carboxylase (PEPC; EC 4.1.1.31), three isoforms of pyruvate orthophosphate $(\mathrm{Pi})$ dikinase (PPDK; EC 2.7.9.1), precursor of $\beta$-D-glucosidase (EC 3.2.1.21), drought-inducible 22 $\mathrm{kD}$ protein, aspartate aminotransferase (AAT; EC 2.6.1.1) and stromal $70 \mathrm{kDa}$ heat shock-related protein were found to be increased in abundance (Table 3). The expression of putative peptidyl-prolyl cis-trans isomerase family protein isoform1 (PPIase; EC 5.2.1.8) and cps2 was decreased.

In summary, Venn diagrams (Fig. 10) show that of all maize leaf 8 proteins that increased in abundance, none were found to be shared by the tested classes $[\mathrm{Tu}+(8)$; $\mathrm{D}+(8) ; \mathrm{Tu}+\mathrm{D}(8)]$, whereas of all the proteins that decreased in abundance, only cps 2 was affected by the $\mathrm{D}+(8)$ and $\mathrm{Tu}+\mathrm{D}(8)$ stresses.

The comparison of leaf $8[\mathrm{C}(8)]$ with leaf $9[\mathrm{C}(9)]$ protein profiles shows that in leaf 9 , which was younger than leaf 8, ATP synthase CF1 $\alpha$ subunit (atpA; EC 3.6.3.14) was increased in abundance while pyruvate phosphate dikinase (PPDK) and two other proteins involved in glycolysis [fructose-bisphosphate aldolase (EC 4.1.2.13), glyceraldehyde-3-phosphate dehydrogenase (GAPDH; EC 1.2.1.12) were decreased in abundance (Table 3). Similarly, the comparison of noninfested leaf 9 [Tu - (9)] from mite-infested plants with leaf 9 from control plants $[\mathrm{C}(9)]$ reveals that atpA was increased in abundance, while PPDK, two GAPDH isoforms and fructose-bisphosphate aldolase were decreased. In the mite undamaged leaf 9 [Tu - (9)] above the mite-damaged leaf $8[\mathrm{Tu}+(8)]$, the abundance of five proteins was 
Fig. 9 Dendrograms for 36 samples obtained from six classes $[\mathrm{C}(8), \mathrm{Tu}+(8)$, $\mathrm{Tu}+\mathrm{D}(8), \mathrm{D}+(8), \mathrm{C}(9)$, $\mathrm{Tu}-(9)$ ] augmented with the heat map of centred data matrix (with columns and rows sorted out in the corresponding dendrograms). Gradations of colour from dark blue to red in the colour bar indicate the increase in value of data elements

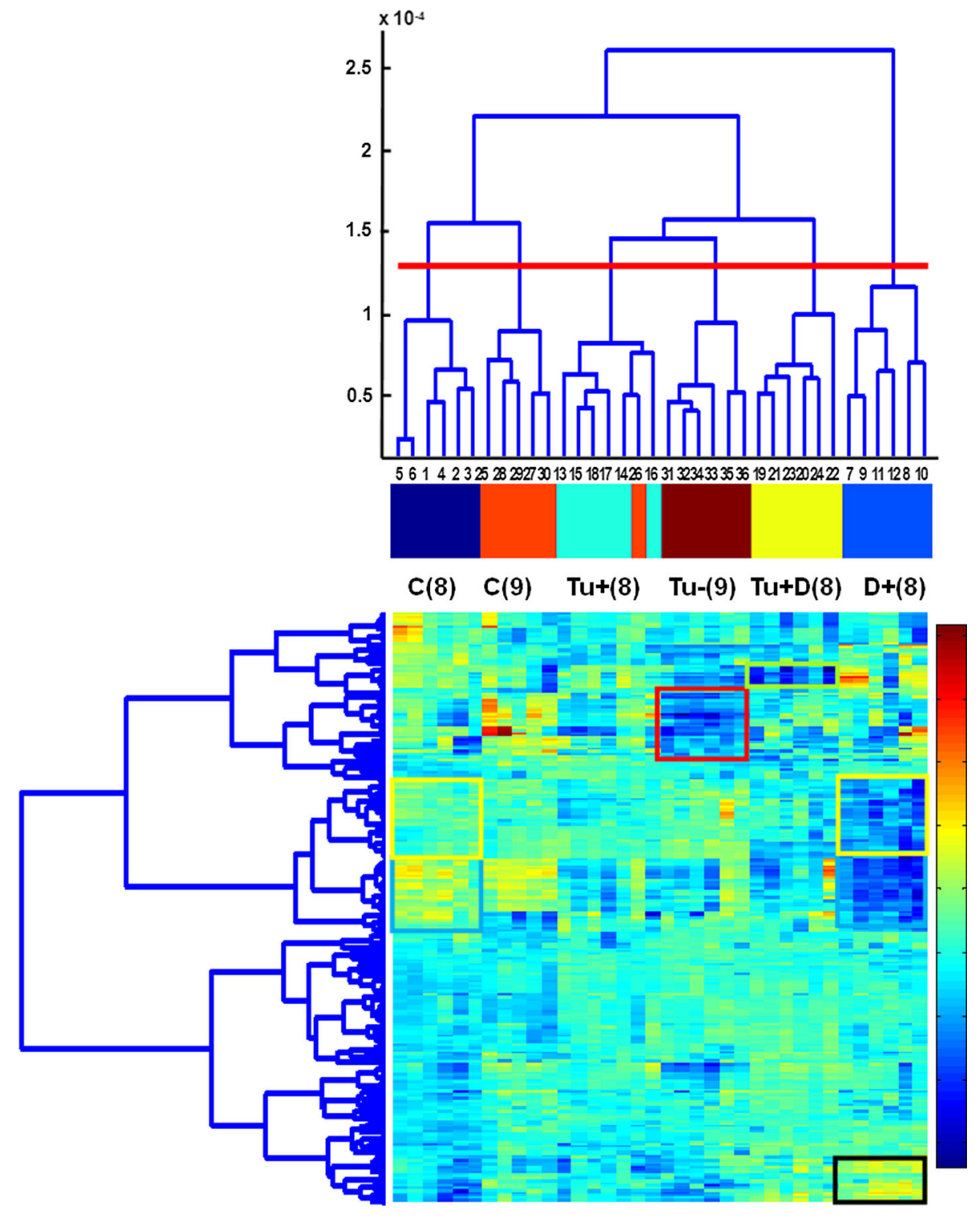

Fig. 10 Venn diagrams showing the overlapping of increased (a) or decreased (b) abundance of maize leaf proteins upon mite infestation $[\mathrm{Tu}+(8)]$, soil drought $[(\mathrm{D}+(8)]$ and a combination of stresses $[\mathrm{Tu}+\mathrm{D}(8)]$
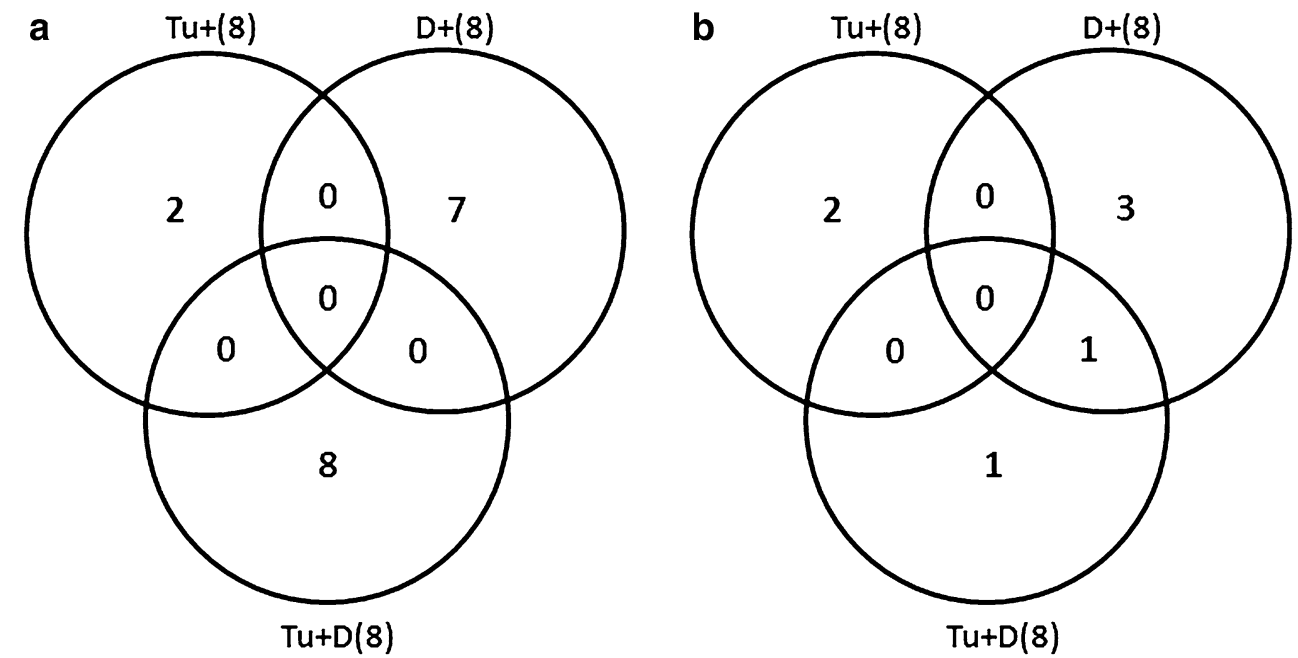
systemically changed (Table 3). The abundance of RuBisCO large subunit-binding protein subunit $\beta$, fructosebisphosphate aldolase and superoxide dismutase [Mn] 3.4, mitochondrial precursor (Mn-SOD; EC 1.15.1.1) was increased, whereas the expression of fructose-bisphosphate aldolase and GAPDH was decreased.

\section{Discussion}

\section{Oxidative stress-related enzymes and soluble proteins}

Our study shows that soil water deficiency and mite feeding stresses, when imposed individually, increased the guaiacol POX and GR activities and diminished the CAT activity in maize leaf 8 . Similarly, CAT-2 isoform (the main contributor engaged in the removal of photorespiratory $\mathrm{H}_{2} \mathrm{O}_{2}$ ) decreased in both mite-infested maize and citrus leaf tissues (Maserti et al. 2011; Świątek et al. 2014) as well as in drought-stressed non-Bt maize (Świątek et al. 2014). Under drought, the APX was more responsive than the CAT. It suggests that intracellular $\mathrm{H}_{2} \mathrm{O}_{2}$ level could be controlled by CAT-independent pathways (Mhamdi et al. 2010; Brossa et al. 2015). The rise in the GR activities under individually applied drought and mite stresses implies enhanced regeneration of reduced glutathione (GSH) from oxidized glutathione (GSSG) in the ascorbateglutathione cycle (Foyer and Noctor 2011). The observed here changes in the activity of GR were more pronounced under drought than mite stress. Interestingly, the combined effects of these two stresses resulted in the decreased GR activity, whereas the POX and APX activities remained at the level noted for soil drought stress. The increase of POX activity when maize leaf has been affected by both mite and drought stresses, acting separately or together, seems to confirm the enzyme involvement in the plant defensive processes (e.g., ROS metabolism regulation, lignin/suberin formation, cross-linking of cell wall polymers, hypersensitive responses, etc.) as in the case of other plant species either infested with phytophagous mites (Stout et al. 1996; Kielkiewicz 2002) or subjected to soil drought (Lee et al. 2007).

PPO is involved in plant defence against various stresses, including soil drought (Mayer 2006) and mite infestation (Duffey and Felton 1991; Stout et al. 1996; Kielkiewicz 2002). PPO catalyses the oxidization of cell wall cross-linking phenolics and phenolic polymerization to highly reactive quinones, that may convert amino acids into antinutritive compounds for herbivorous pests (Duffey and Felton 1991). The enhanced PPO activity in the dehydrated maize leaf 8 on one hand, and the inhibited one in the mite-infested leaf on the other, which was observed in this study, suggest that the PPO responds differently to each of the individual stresses. However, it is not quite clear whether strong stimulation of the PPO activity is beneficial or detrimental to drought-stressed plants (Mayer 2006). In comparison to the effect of both stresses applied individually, the combined effect of soil drought and mite feeding stresses resulted in an increased activity of SOD and reduced activity of GR and PPO, suggesting distinct defence responses, which is in accordance with the current research (Prasch and Sonnewald 2015).

Finally, it is worth noting that in leaf 9 (free of mites and in close proximity to mite-infested leaf 8), the APX activity increase and the simultaneous decrease in the activity of SOD, GR and PPO, indicate the systemic effect of mite infestation, in which ascorbate-glutathione cycle enzymes and enzyme-oxidizing phenols are thought to be involved. Although there is an increasing evidence confirming antioxidant enzymes and phytohormones engagement in systemic responses monitoring biotic/abiotic tolerance (Zebelo and Maffei 2015; Xia et al. 2015), further research is needed for a full understanding of the phenomenon in the C4 monocot-mite interactions.

In this study, we observed that soil drought stress drastically reduced the maize leaf hydration, but co-occurring mite infestation did not contribute to further leaf water content decrease. Similarly, soil drought or mite feeding, occurring individually, decreased the soluble protein content, while the combined stresses were not additive in this respect. The decline in the content of soluble proteins seems to have been caused by the intensified degradation of damaged or unnecessary proteins (Benešová et al. 2012). Inactivation or breakdown of proteins may also result from protein carbonylation, the major form of protein oxidation regarded as a marker for oxidative stress (Levine 2002). The dehydration-induced increase in both protein carbonylation and activity of antioxidant enzymes (SOD, APX, GR, POX, PPO), shown in the present paper, suggests that a 6-day soil water deficit resulted in protein oxidative damage in maize leaves. This is consistent with the decrease in the efficiency of photosystem (PS)II photochemistry (Fv/Fm), a widely used parameter to assess the photosynthetic apparatus functioning under stress conditions (Brossa et al. 2015), from $0.739 \pm 0.066$ in control leaf to $0.601 \pm 0.063$ in drought-stressed leaf (data not shown). However, the effect of mite feeding stress on the induction of leaf oxidative stress is less evident. In miteinfested leaves, the increase in oxidative carbonylation coincided with the reduced CAT, APX and PPO activity at a constant $\mathrm{Fv} / \mathrm{Fm} \quad(0.772 \pm 0.015$ as compared to $0.739 \pm 0.066$ for control leaves). Surprisingly, under both stresses, protein carbonylation decreased despite the increased activity of all antioxidant enzymes (except the CAT activity) and Fv/Fm decreased from $0.739 \pm 0.066$ to 
$0.592 \pm 0.073$ (data not shown). In light of our data, protein carbonylation is not directly linked to oxidative stress based on the assessment of ROS enzymatic scavengers. Protein carbonylation may also be a result of diminished capacity of oxidized protein removal, increased protein susceptibility to oxidative attack or other unknown yet interrelations. It should be underlined that the determination of carbonylated proteins points only on the type of posttranslational protein modification, but protein network modification under simultaneously applied biotic/abiotic stresses remains unknown.

\section{Maize leaf proteome}

To the best of our knowledge, the proteome analysis was not previously carried out to reveal the differences in the defensive responses of commercial maize to environmental stresses, such as mite infestation and soil drought, applied either individually or in combination. A multivariate analysis (UVE-PLS) allowed to identify 94 protein spots (out of 358 considered) which differentiated the studied treatments. Only 43 of them had individual discrimination power, and they were positively identified by searching across protein database of NCBI-NR and grouped by their biological relevance. Upon mite feeding, the abundance of RuBisCO that fix $\mathrm{CO}_{2}$ in Calvin-Benson cycle decreased in maize leaf 8 , as it was previously observed in rice on which the brown planthopper (Nilaparvata lugens Stål) fed, in Nicotiana attenuate plants on which the Manduca sexta caterpillars fed, in Solanum tuberosum L. plants infested with the Colorado potato beetle (Leptinotarsa decemlineata Say) larvae or in tomatoes challenged by the potato aphid (Macrosiphum euphorbiae Thomas) (Giri et al. 2006; Wei et al. 2009; Duceppe et al. 2012; Coppola et al. 2013). Conversely, RuBisCO increased in abundance in citrus leaves on which the two-spotted spider mite fed (Maserti et al. 2011). One of putative reasons of decreased RuBisCO abundance seems to be a coincidental lowered abundance of Cpn60, a recently discovered molecular chaperone responsible for RuBisCO folding and assembly (Trösch et al. 2015).

OEE3 and heat shock cognate $70 \mathrm{kDa}$ (HSC70) protein 2 were induced upon mite feeding. OEE3 is known as one of three proteins forming the oxygen evolving complex (OEC), which maintains the manganese cluster of the PSII complex in a chloroplast. Therefore, it can be reasoned that in mite-infested leaf tissue, OEE3-enhanced abundance improved the light-capturing ability protecting the leaf against photoinhibition, as it has been shown in the maize and soybean leaves exposed to short-term mite injuries (De Freitas Bueno et al. 2009). The increased amount of HSC70 protein2, one of the stress-inducible heat shock protein (HSP70) homologs which exhibits low constitutive expression, indicates its involvement in stabilising the nascent proteins released from ribosomes, thus protecting the partially synthesized polypeptides from being accidentally misfolded or aggregated (Zhu et al. 2012).

In the drought-stressed maize leaf 8,13 protein spots differed in their expression pattern, and among them, the small and large RuBisCO subunits were increased in abundance, similarly as in the acclimated wheat, barley and sugarcane exposed to soil water deficiency (Zhou et al. 2012; Shanker et al. 2014). Since Cpn60 is uniquely important for RuBisCO folding and assembly (Trösch et al. 2015), its coincidental increase in the dehydrated maize leaf 8 indicates that soil drought did not affect RuBisCO itself. Drought stress-induced abundance of NADP-ME (another photosynthesis-related protein) seems to maintain the rate of the RuBisCO-catalyzed reaction in maize leaf 8 . It was confirmed that NADP-ME activity in rice increased under salt, osmotic and drought stress (Ke et al. 2009), and as NADP-ME was overexpressed, it improved salt and osmotic tolerance in Arabidopsis (Liu et al. 2007) and tobacco (Laporte et al. 2002). It is also well documented that under stress conditions, the reducing power (NADPH) produced by NADP-ME mediated L-malate decarboxylation is used for ROS detoxification (Laporte et al. 2002). The drought-induced abundance of stress-related glyoxylase 1, one of two enzymes of the glyoxalase system, which is the major pathway of metabolism of methylglyoxal (MG) in the cytosol and mitochondria, illustrates the effectiveness of cytotoxic MG and other 2-oxoaldehydes conversion into 2-hydroxyacids, using GSH as a cofactor, in an irreversible two-step reaction. This point to glyoxylase1 engagement into plant tolerance and oxidative defence against soil drought and other abiotic stresses (Zadražnik et al. 2013).

Considering the function of sHSPs-like molecular chaperones that bind partially denatured proteins, one may suppose that, in dehydrated maize leaf 8 , the increase in abundance of $17.5 \mathrm{kDa}$ class II HSP prevents from irreversible protein aggregation. Similarly, overexpression of LOC100192117 (pathogenesis-related PR-10 protein) suggests its protective function (Liu and Ekramoddoullah 2006). Among proteins that decreased in abundance following maize leaf 8 dehydration, ADP-GlcPPase, cps2, RuBisCO large subunit-binding protein subunit $\alpha$ and drought-inducible $22 \mathrm{kDa}$ were identified. The lowered abundance of ADP-GlcPPase suggests that the starch biosynthesis declined because the product (ADP-Glc) of the ADP-GlcPPase catalyzed reaction is the major substrate for starch biosynthesis in photosynthetic and nonphotosynthetic tissues. The limited cps2 expression indicates disorders in the translation process of chloroplast proteins because this protein participates in driving the translation machinery (Belcher et al. 2015). RuBisCO large 
subunit-binding protein subunit $\alpha$ binds RuBisCO small and large subunits and is involved in the assembly of the enzyme oligomer (Hauser et al. 2015). Its decreased abundance, together with the decreased abundance of cps2, gives an indication of drought-induced impairment of protein biosynthesis. The lowered expression of $22 \mathrm{kDa}$ protein implies that it was not involved in improving maize tolerance to short-term water deficit. Nevertheless, $22 \mathrm{kDa}$ protein contributes to acclimation of sugarcane seedlings to osmotic stress (Zhou et al. 2012) and to maize defence against pathogens (Huang et al. 2009).

We documented that the proteome response of maize leaf 8 to the combined mite and drought stresses significantly differed from those induced by each stress applied individually, which is consistent with current research (Atkinson and Urwin 2012; Atkinson et al. 2013; Prasch and Sonnewald 2015). The combined stresses result in the increased abundance of PEPC, PPDK isoforms, AAT, as well as the proteins with potential protective functions $(\beta-$ D-glucosidase precursor, predicted stromal $70 \mathrm{kDa}$ heat shock-related protein, drought-inducible $22 \mathrm{kDa}$ protein). We therefore assume that these proteins are responsible for maize adjustment to novel environmental conditions. PEPC (one of the essential cytosolic enzyme in the C4 photosynthesis) was induced by soil drought, salt and cold (Doubnerová and Ryšlavá 2011), but nothing is known about PEPC involvement in response to mite-pest infestation. In a transgenic maize line, higher drought tolerance was related to PEPC overexpression (Jeanneau et al. 2002), but in Sorghum bicolor genotypes, it was not (Jedmowski et al. 2013). The increased abundance of another protein-PPDK (catalysing the formation of phosphoenolpyruvate, PEP) in maize leaf 8 by combined stresses is in full agreement with PPDK up-regulation in drought tolerant genotypes of Sorghum bicolor (Jedmowski et al. 2013) and higher drought tolerance in rice (Gu et al. 2013). We are unable to indicate which form of PPDK was increased (the cytoplasmic or the chloroplastic). Despite that one may suppose that the PEPC and PPDKs increased abundance improves the efficiency of carbon fixation in maize leaf 8 under simultaneously applied soil drought and mite feeding stresses. Moreover, due to the elevated abundance of PEPC and PPDK, many metabolic pathways (including citric acid cycle or amino acid synthesis) should be provided by an increased level of intermediates. This suggestion is in accordance with the increased abundance of AAT that may result in greater availability of aspartate to biosynthesis of the aspartatefamily amino acids (methionine, lysine, asparagine). In Arabidopsis, under the combined soil drought and nematode attack, the methionine metabolism was intensified, resulting in higher tolerance to the pest infestation (Atkinson et al. 2013).
$\beta$-D-glucosidase abundance, which increased in maize leaf 8 under soil drought and mite feeding acting as one, suggests the contribution of the enzyme to support plant defence. However, the elevated activity of $\beta$-D-glucosidase is indicative of intensified lignification, phytohormones production from Glc-conjugates or plant defending activity against biotic/abiotic stresses (Morant et al. 2008). $\beta$-Dglucosidase has also been shown to activate DIMBOA, a secondary maize metabolite that is toxic to chewing and phloem-feeding herbivores (Pentzold et al. 2014).

Under combined drought and mite stresses, a maize plant defended itself by increasing the expression of HSP70-class molecular chaperones. The enhanced expression of HSP70 should protect plants against stress-induced improper folding/refolding polypeptides and facilitate degradation of unstable proteins, protein aggregate solubilisation, protein complexes disassembly and control of membrane translocation (Gupta and Tuteja 2011; Trösch et al. 2015 and rfs therein). When the stresses overlapped, the drought-inducible $22 \mathrm{kDa}$ protein was also found to have been raised in maize leaf 8 . However, it decreased in a dehydrated maize leaf. This clearly shows that unlike the separately applied soil drought stress, the mite feeding stress truly induces the expression of drought-inducible $22 \mathrm{kDa}$ protein when maize is under double stress.

Among the proteins decreased in abundance under coexisting stresses, there were cps 2 (decreased by water deficit as well), peptidyl-prolyl cis-trans isomerase (PPIase) and an unknown protein. PPIase is one of two foldases known to be involved in folding and trafficking proteins (Gupta and Tuteja 2011). White pine weevil-induced tissue of Sitka spruce (Lippert et al. 2007) showed to be overabundant in PPIase, whereas the reduced abundance of PPIase in the double stressed maize leaf 8 tissues seems to implicate the proper protein folding disruption.

AtpA, known as energy metabolism-related protein, was found to be overabundant in the noninfested leaf 9 of a mite-infested plant. This may imply a higher demand for ATP to improve stress tolerance in the noninfested leaf 9 of mite-infested maize plant. The abundance of PPDK, as well as glycolytic protein (fructose-bisphosphate aldolase and GAPDH) isoforms was decreased.

A comparison of proteome of the noninfested maize leaf 9 with proteome of the mite-infested leaf 8 revealed changed expressions of five proteins. RuBisCO large subunit-binding protein (subunit $\beta$ ), one of fructose-bisphosphate aldolase isoforms and mitochondrial precursor of Mn-SOD, belonged to proteins that increased in abundance, while another fructose-bisphosphate aldolase isoform and GAPDH were lowered in abundance. RuBisCO large subunit-binding protein (subunit $\beta$ ) belongs to the chaperonin (HSP60) family that binds RuBisCO small and 
large subunits and is involved in assembling the oligomer enzyme (Trösch et al. 2015). However, as we still do not know how systemically it works, the issue needs to be further investigated.

Fructose-bisphosphate aldolase exists in the chloroplastic and cytosolic isoforms, and in the noninfested leaf 9, it was identified as two spots. One of them decreased in abundance while the other one increased. This shows that fructose-bisphosphate aldolase is not only regulated by the abiotic stresses as it was shown previously (Houston et al. 2009), but also by the mite-pest stress and in a systemic way. The elevated abundance of Mn-SOD indicates that one of the predominant SOD isoforms responds systemically to biotic stress. Up to now, the enhancement of MnSOD activity was documented in citrus leaves on which mite fed locally (Maserti et al. 2011).

\section{Concluding remarks and perspectives}

Taken together, multivariate chemometric methods for analysing proteomic data reveal that the changes in the maize leaf proteome under soil drought stress are greater than those under mite infestation stress or under both stresses combined. Nevertheless, a particular adjustment in the maize leaf proteome profile under separately or simultaneously applied stresses was documented. For example, it was shown that mite infestation decreases the abundance of leaf maize proteins related to photosynthesis, whereas soil drought increases it. In the mite-injured leaves, proteins which protect the photosynthetic apparatus against photoinhibition increase in abundance. Both stresses, when acting simultaneously, elevate the amount of proteins that enable maize to maintain the efficiency of photosynthesis and metabolism, as well as to protect its cells against metabolic injuries. It is noteworthy that soil drought co-occurring with mite infestation increases the abundance of photosynthesis-related proteins (PEPC, PPDK) located in the mesophyll cells, whereas soil drought acting individually increases the abundance of NADP-ME functioning in the bundle sheath cells. Consequently, PEPC, PPDK and NADP-ME can be differently modified to improve maize efficiency of $\mathrm{CO}_{2}$ fixation upon individual and double stresses.

The results presented in this study confirm that the overabundance of relevant proteins should be an adequate method to improve plant crop tolerance to joint stresses. Further analyses of the overexpressed/silenced monocot mutants will have to be made to explore the functions of proteins modified under individual/coexisting stresses in greater detail. The results of such research, together with applied proteomic approach, should significantly contribute to developing maize genotypes able to tolerate coexisting environmental stresses.
Author contribution statement $\mathrm{MK}$ and $\mathrm{BZ}$ designed research and wrote this paper. $\mathrm{MN}$ conducted proteomic experiments. AD, MN, DS- $€$, AM carried out biochemical analyses. BW and MK analysed data. All authors participated in the analysis of this study and read the final version submitted.

Acknowledgments This study was supported by a Grant NN310038338 from the Ministry of Science and Higher Education (Poland).

\section{Compliance with ethical standards}

Conflict of interest The authors declare that they have no conflict of interest.

\section{References}

Atkinson NJ, Urwin PE (2012) The interaction of plant biotic and abiotic stresses: from genes to the field. J Exp Bot 63:3523-3543. doi:10.1093/jxb/ers100

Atkinson NJ, Lilley CJ, Urwin PE (2013) Identification of genes involved in the response of Arabidopsis to simultaneous biotic and abiotic stresses. Plant Physiol 162:2028-2041. doi:10.1104/ pp.113.222372

Barrs HD (1968) Determination of water deficits in plant tissue. In: Kozlowski TT (ed) Water deficits and plant growth. Academic Press, New York, pp 235-368

Baxter A, Mittler R, Suzuki N (2014) ROS as key players in plant stress signalling. J Exp Bot 65:1229-1240. doi:10.1093/jxb/ ert375

Beers RF, Sizer IW (1952) A spectrophotometric method for measuring the breakdown of hydrogen peroxide by catalase. J Biol Chem 195:133-140

Belcher S, Williams-Carrier R, Stiffler N, Barkan A (2015) Largescale genetic analysis of chloroplast biogenesis in maize. BBABioenergetics 1847:1004-1016. doi:10.1016/j.bbabio.2015.02. 014

Benešová M, Hola D, Fischer L, Jedelsky PL, Hnilicka F, Wilhelmova N, Rothová O, Kočová M, Procházková D, Honnerová J, Fridrichová L, Hniličková H (2012) The physiology and proteomics of drought tolerance in maize: early stomatal closure as a cause of lower tolerance to short-term dehydration? PLoS One 7:e38017. doi:10.1371/journal.pone.0038017

Bradford MM (1976) Rapid and sensitive method for the quantitation of microgram quantities of protein utilizing the principle of protein-dye binding. Anal Biochem 72:248-254. doi:10.1016/ 0003-2697(76)90527-3

Brossa R, Pinto-Marijuan M, Francisco R, López-Carbonell M, Chaves MM, Alegre L (2015) Redox proteomics and physiological responses in Cistus albidus shrubs subjected to long-term summer drought followed by recovery. Planta 241:803-822. doi:10.1007/s00425-014-2221-0

Coppola V, Coppola M, Rocco M, Digilio MC, D'Ambrosio C, Renzone G, Martinelli R, Scaloni A, Pennacchio F, Rao R, Corrado G (2013) Transcriptomic and proteomic analysis of a compatible tomato-aphid interaction reveals a predominant salicylic acid-dependent plant response. BMC Genom 14:515. doi:10.1186/1471-2164-14-515

Cullen E, Schramm S (2009) Two-spotted spider mite management in soybean and corn. Cooperative Extension of the University of 
Wisconsin-Extension. A3890. www.uwex.edu/ces/cty. Accessed 1 Oct 2009

Daszykowski M, Serneels S, Kaczmarek K, Van Espen P, Croux C, Walczak B (2007) TOMCAT: a MATLAB toolbox for multivariate calibration techniques. Chemometr Intell Lab 85:269-277. doi:10.1016/j.chemolab.2006.03.006

De Freitas Bueno A, de Freitas Bueno RC, Nabity PD, Higley LG, Fernandes OA (2009) Photosynthetic response of soybean to two-spotted spider mite (Acari: Tetranychydae) injury. Braz Arch Biol Tech 52:825-834

Doubnerová V, Ryšlavá H (2011) What can enzymes of C4 photosynthesis do for C3 plants under stress? Plant Sci 180:575-583. doi:10.1016/j.plantsci.2010.12.005

Duceppe MO, Cloutier C, Michaud D (2012) Wounding, insect chewing and phloem sap feeding differentially alter the leaf proteome of potato, Solanum tuberosum L. Proteome Sci 10:1-14. doi:10.1186/1477-5956-10-73

Duffey SS, Felton GW (1991) Enzymatic antinutritive defenses of the tomato plant against insects. In: Hedin PA (ed) Naturally occurring pest bioregulators. ACS Symposium Series 449. Dallas, Fall, 1989. American Chemical Society, Washington DC, pp 167-197

Foyer CH, Halliwell B (1976) The presence of glutathione and glutathione reductase in chloroplasts: a proposed role in ascorbic acid metabolism. Planta 133:21-25

Foyer CH, Noctor G (2011) Ascorbate and glutathione: the heart of the redox hub. Plant Physiol 155:2-18. doi:10.1104/pp.110. 167569

Fridovich I (1986) Biological effects of the superoxide radical. Arch Biochem Biophys 247:1-11. doi:10.1016/0003-9861(86)90526-

Gawrońska H, Kiełkiewicz M (1999) Effect of the carmine spider mite (Acarida: Tetranychidae) infestation and mechanical injury on the level of ABA in tomato plants. Acta Physiol Plant 21:297-303

Giri AP, Wunsche H, Mitra S, Zavala JA, Muck A, Svatos A, Baldwin IT (2006) Molecular interactions between the specialist herbivore Manduca sexta (Lepidoptera, Sphingidae) and its natural host Nicotiana attenuata. VII. Changes in the plant's proteome. Plant Physiol 142:1621-1641. doi:10.1104/pp.106.088781

Grudkowska M, Zagdańska B (2010) Acclimation to frost alters proteolytic response of wheat seedlings to drought. J Plant Physiol 167:1321-1327. doi:10.1016/j.jplph.2010.05.019

Gu JF, Qiu M, Yang JC (2013) Enhanced tolerance to drought in transgenic rice plants overexpressing $\mathrm{C} 4$ photosynthesis enzymes. Crop J 1:105-114. doi:10.1016/j.cj.2013.10.002

Gupta D, Tuteja N (2011) Chaperones and foldases in endoplasmic reticulum stress signaling in plants. Plant Signal Behav 6:232-236. doi:10.4161/psb.6.2.15490

Hauser T, Popilka L, Hartl FU, Hayer-Hartl M (2015) Role of auxiliary proteins in Rubisco biogenesis and function. Nat Plants 2(1): 15065 . doi: $10.1038 /$ nplants.2015.65

Houston NL, Hajduch M, Thelen JJ (2009) Quantitative proteomics of seed filling in castor: comparison with soybean and rapeseed reveals differences between photosynthetic and nonphotosynthetic seed metabolism. Plant Physiol 151:857-868. doi:10.1104/ pp.109.141622

Huang X, Liu L, Chen J, Zhai Y (2009) Comparative proteomic analysis of the response in resistant and susceptible maize inbred lines to infection by Curvularia lunata. Prog Nat Sci 19:845-850. doi:10.1016/j.pnsc.2008.07.024

Jeanneau M, Gerentes D, Foueillassar X, Zivy M, Vidal J, Toppan A, Perez P (2002) Improvement of drought tolerance in maize: towards the functional validation of the Zm-Asrl gene and increase of water use efficiency by over-expressing C4-PEPC. Biochimie 84:1127-1135. doi:10.1016/S0300-9084(02)00024-X
Jedmowski C, Ashoub A, Bruggemann W (2013) Reactions of Egyptian landraces of Hordeum vulgare and Sorghum bicolor to drought stress, evaluated by the OJIP fluorescence transient analysis. Acta Physiol Plant 35:345-354. doi:10.1007/s11738012-1077-9

Ke Y, Han G, He H, Li J (2009) Differential regulation of proteins and phosphoproteins in rice under drought stress. Biochem Biophys Res Co 379:133-138. doi:10.1016/j.bbrc.2008.12.067

Kielkiewicz M (1999) Ultrastructural cell modification in tomato (Lycopersicon esculentum) leaf tissue in response to the carmine spider mite (Tetranychus cinnabarinus) feeding. In: Bruin J, van der Geest LPS, Sabelis MW (eds) Ecology and evolution of the Acari. Kluver Academic Publishers, Dordrecht/Boston/London, pp 603-615

Kielkiewicz M (2002) Influence of carmine spider mite Tetranychus cinnabarinus Boisd. (Acarina: Tetranychidae) feeding on ethylene production and the activity of oxidative enzymes in damaged tomato plants. In: Bernini F, Nannelli R, Nuzzaci G, de Lillo E (eds) Acari: Phylogeny and evolution. Adaptations in mites and ticks. Kluwer Academic Publishers, The Netherlands, pp 389-392

Laporte MM, Shen B, Tarczynski MC (2002) Engineering for drought avoidance: expression of maize NADP-malic enzyme in tobacco results in altered stomatal function. J Exp Bot 53:699-705. doi:10.1093/jexbot/53.369.699

Lee BR, Kim KY, Jung WJ, Avice JC, Ourry A, Kim TH (2007) Peroxidases and lignification in relation to the intensity of waterdeficit stress in white clover (Trifolium repens L.). J Exp Bot 58:1271-1279. doi:10.1093/jxb/erl280

Levine RL (2002) Carbonyl modified proteins in cellular regulation, aging, and disease. Free Radic Biol Med 32:790-796. doi:10. 1016/S0891-5849(02)00765-7

Levine RL, Williams JA, Stadtman ER, Shacter E (1994) Carbonyl assays for determination of oxidatively modified proteins. Methods Enzymol 233:346-357. doi:10.1016/S00766879(94)33040-9

Lippert D, Chowrira S, Ralph SG, Zhuang J, Aeschliman D, Ritland C, Ritland K, Bohlmann J (2007) Conifer defense against insects: proteome analysis of Sitka spruce (Picea sitchensis) bark induced by mechanical wounding or feeding by white pine weevils (Pissodes strobi). Proteomics 7:248-270. doi:10.1002/ pmic. 200600525

Liu JJ, Ekramoddoullah AK (2006) The family 10 of plant pathogenesis-related proteins: their structure, regulation, and function in response to biotic and abiotic stresses. Physiol Mol Plant Path 68:3-13. doi:10.1016/j.pmpp.2006.06.004

Liu S, Cheng Y, Zhang X, Guan Q, Nishiuchi S, Hase K, Takano T (2007) Expression of an NADP-malic enzyme gene in rice (Oryza sativa L.) is induced by environmental stresses; overexpression of the gene in Arabidopsis confers salt and osmotic stress tolerance. Plant Mol Biol 64:49-58. doi:10.1007/s11103007-9133-3

Maserti BE, Del Carratore R, Della Croce CM, Podda A, Migheli Q, Froelicher Y, Lurog F, Morillonh R, Ollitrault P, Taloni M, Rossignol M (2011) Comparative analysis of proteome changes induced by the two spotted spider mite Tetranychus urticae and methyl jasmonate in citrus leaves. J Plant Physiol 168:392-402. doi:10.1016/j.jplph.2010.07.026

Mayer AM (2006) Polyphenol oxidases in plants and fungi: going places? A review. Phytochemistry 67:2318-2331. doi:10.1016/j. phytochem.2006.08.006

Meissle M, Álvarez-Alfageme F, Bigler F, Bohan DA, Devos Y, Malone LA, Pons X, Rauschen S, Romeis J (2013) Arthropods in European maize fields-describing the receiving environment for the risk assessment of GM crops. GMOs in integrated plant production. IOBC-WPRS Bulletin 97:81-87 
Mhamdi A, Queval G, Chaouch S, Vanderauwera S, Van Breusegem F, Noctor G (2010) Catalase function in plants: a focus on Arabidopsis mutants as stress-mimic models. J Exp Bot 61:4197-4220. doi:10.1093/jxb/erq282

Morant AV, Jørgensen K, Jørgensen C, Paquette SM, Sanchez-Perez R, Møller BL, Bak S (2008) $\beta$-Glucosidases as detonators of plant chemical defense. Phytochemistry 69:1795-1813. doi:10. 1016/j.phytochem.2008.03.006

Nakano Y, Asada K (1981) Hydrogen peroxide is scavenged by ascorbate-specific peroxidase in spinach chloroplasts. Plant Cell Physiol 22:867-880

Nguyen D, Rieu I, Mariani C, van Dam NM (2016) How plants handle multiple stresses: hormonal interactions underlying responses to abiotic stress and insect herbivory. Plant Mol Biol. doi:10.1007/s11103-016-0481-8

Patykowski J, Majczak A, Bergier K, Skłodowska M (2007) Ascorbate content and peroxidase activities in apple fruits during storage. J Fruit Ornam Plant Res 15:21-33

Pentzold S, Zagrobelny M, Rook F, Bak S (2014) How insects overcome two-component plant chemical defence: plant $\beta$ glucosidases as the main target for herbivore adaptation. Biol Rev 89:531-551. doi:10.1111/brv.12066

Prasch CM, Sonnewald U (2015) Signaling events in plants: stress factors in combination change the picture. Environ Exp Bot 114:4-14. doi:10.1016/j.envexpbot.2014.06.020

Rollins JA, Habte E, Templer SE, Colby T, Schmidt J, von Korff M (2013) Leaf proteome alterations in the context of physiological and morphological responses to drought and heat stress in barley (Hordeum vulgare L.). J Exp Bot 64:3201-3212. doi:10.1093/ jxb/ert158

Shanker AK, Maheswari M, Yadav SK, Desai S, Bhanu D, Attal NB, Venkateswarlu B (2014) Drought stress responses in crops. Funct Integr Genomics 14:11-22. doi:10.1007/s10142-0130356-X

Smoliński A, Walczak B, Einax JW (2002) Hierarchical clustering extended with visual complements of environmental data set. Chemometr Intell Lab 64:45-54. doi:10.1016/S01697439(02)00049-7

Stout MJ, Workman KV, Duffey SS (1996) Identity, spatial distribution and variability of induced chemical responses in tomato plants. Entomol Exp App 79:255-271

Suzuki N, Rivero RM, Shulaev V, Blumwald E, Mittler R (2014) Abiotic and biotic stress combinations. New Phytol 203:32-43. doi:10.1111/nph.12797

Świątek M, Kiełkiewicz M, Zagdańska B (2014) Insect-resistant Btmaize response to the short-term non-target mite-pest infestation and soil drought. Acta Physiol Plant 36:2705-2715. doi:10.1007/ s11738-014-1641-6

Trösch R, Mühlhaus T, Schroda M, Willmund F (2015) ATPdependent molecular chaperones in plastids-more complex than expected. BBA-Bioenergetics 1847:872-888. doi:10.1016/j. bbabio.2015.01.002

Wei Z, Hu W, Lin Q, Cheng X, Tong M, Zhu L, Chen R, He G (2009) Understanding rice plant resistance to the brown planthopper (Nilaparvata lugens): a proteomic approach. Proteomics 9:2798-2808. doi:10.1002/pmic.200800840

Xia XJ, Zhou YH, Shi K, Zhou J, Foyer CH, Yu JQ (2015) Interplay between reactive oxygen species and hormones in the control of plant development and stress tolerance. J Exp Bot 66:2839-2856. doi:10.1093/jxb/erv089

Zadražnik T, Hollung K, Egge-Jacobsen W, Meglič V, Šuštar-Vozlič J (2013) Differential proteomic analysis of drought stress response in leaves of common bean (Phaseolus vulgaris L.). J Proteomic 78:254-272. doi:10.1016/j.jprot.2012.09.021

Zauberman G, Ronen R, Akerman M, Weksler A, Rot I, Fuchs Y (1991) Post-harvest retention of the red color of litchi fruit pericarp. Sci Hort 47:89-97. doi:10.1016/0304-4238(91)90030-3

Zebelo SA, Maffei ME (2015) The role of early signalling events in plant-insect interactions. J Exp Bot 66:435-448. doi:10.1093/ jxb/eru 480

Zerzucha P, Boguszewska D, Zagdańska B, Walczak B (2012) Nonparametric multivariate analysis of variance in the proteomic response of potato to drought stress. Anal Chim Acta 719:1-7. doi:10.1016/j.aca.2011.12.044

Zhou G, Yang LT, Li YR, Zou CL, Huang LP, Qiu LH, Huang X, Srivastava MK (2012) Proteomic analysis of osmotic stressresponsive proteins in sugarcane leaves. Plant Mol Biol Report 30:349-359. doi:10.1007/s11105-011-0343-0

Zhu J, Huang X, Liu T, Gao S, Chen J (2012) Cloning and function analysis of a drought-inducible gene associated with resistance to Curvularia leaf spot in maize. Mol Biol Rep 39:7919-7926. doi:10.1007/s11033-012-1636-6

Zhurov V, Navarro M, Bruinsma KA, Arbona V, Santamaria ME, Cazaux M, Wybouw N, Osborne EJ, Ens C, Rioja C, Vermeirssen V, Rubio-Somoza I, Krishna P, Diaz I, Schmid M, Gómez-Cadenas A, Van dePeer Y, Grbic M, Clark RM, Van Leeuwen T, Grbic V (2014) Reciprocal responses in the interaction between Arabidopsis and the cell-content-feeding chelicerate herbivore spider mite. Plant Physiol 164:384-399. doi:10.1104/pp.113.231555 